630.7

I $66 \mathrm{~b}$

no. 724

cop. 8 



\section{UNIVERSITY OF ILLINOIS LIBRARY AT URBANA.CHAMPAIGN AGRICULTURE}




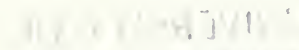

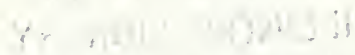

$$
\begin{aligned}
& \text { What a }
\end{aligned}
$$

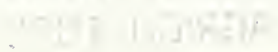




\section{CONTENTS}

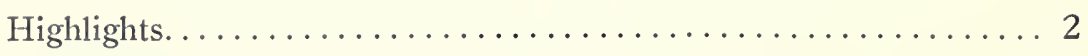

Cattle Rearing in Sierra Leone................... 3

The Musaia Animal Husbandry Station............... 7

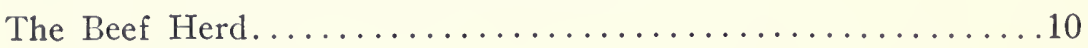

Age at first calving.............................

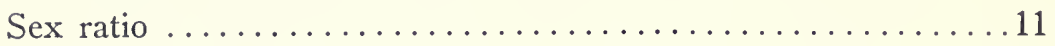

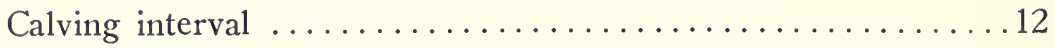

Age at disposal and of animals in the herd.............. 12

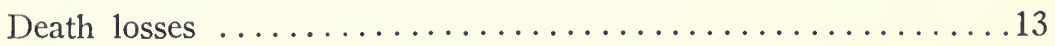

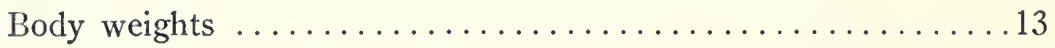

Comparisons of weights of N'Dama, Holstein, and Guernsey cows.30

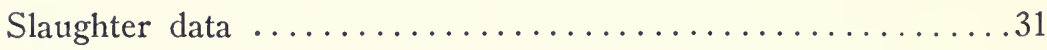

Selection for heavier animals at a given age.............. 34

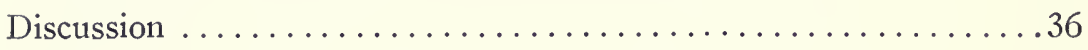

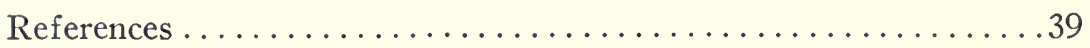

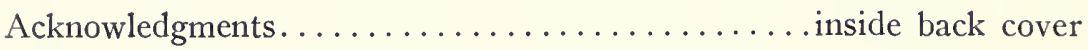
Recommendations $\ldots \ldots \ldots \ldots \ldots \ldots \ldots \ldots \ldots$ back cover

\section{COVER PHOTOS}

Top: A milkmaid and a herd of N'Dama cattle in a warri.

Middle: Selling cottage cheese along a road south of Musaia.

Bottom: N'Dama beef in a meat market in Bo. 


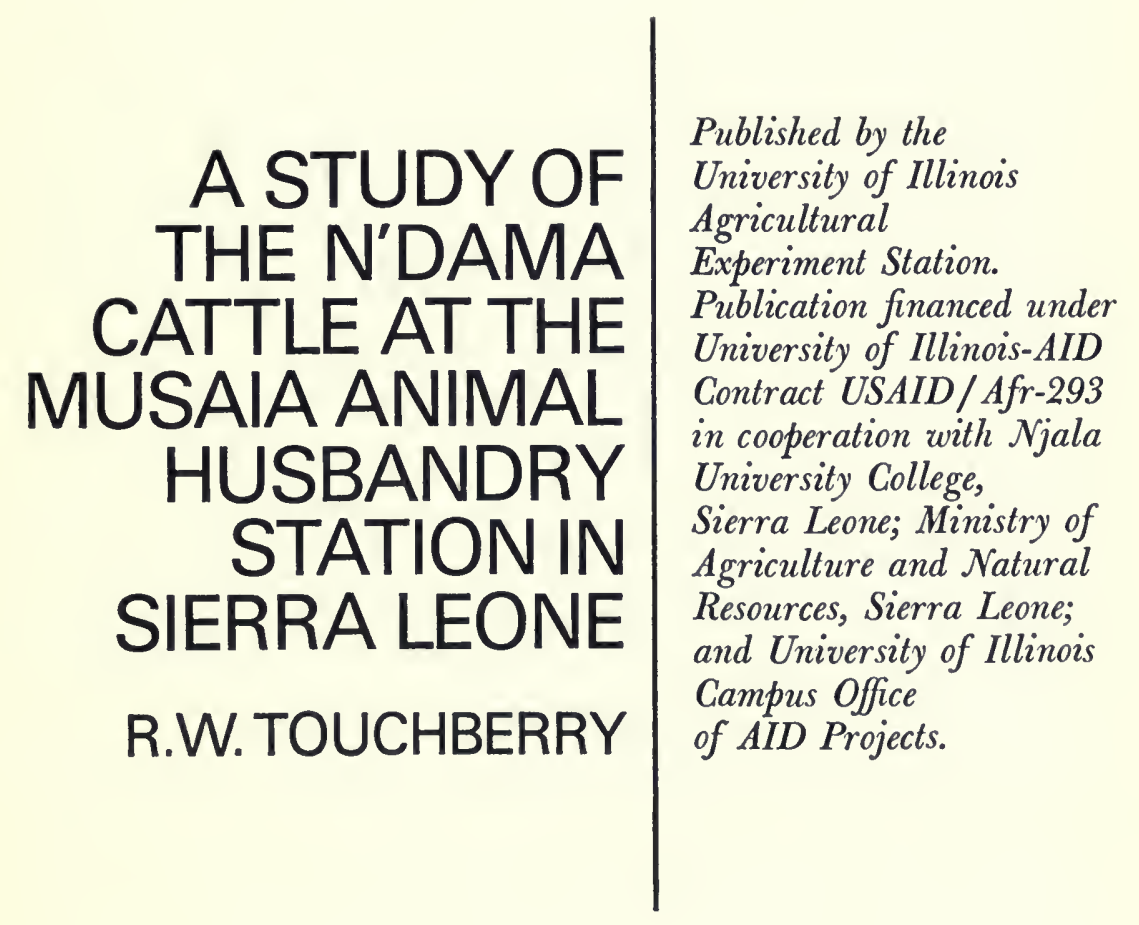




\section{Highlights}

The live weights of the N'Dama cattle at the Musaia Animal Husbandry Station, Musaia, Sierra Leone, have been recorded monthly since 1949. In 1965 live weights were available on $986,871,795,555$, 372 and 182 animals at birth, 6, 12, 24, 36 and 48 months of age. The numbers of males and females did not differ significantly until the age of 36 months.

The average age at first calving was 39.4 months with an average calving interval of 467 days. Most calves were born in the period from September through February. A least squares analysis of the data on weights indicated that the N'Dama cattle at the Musaia station are small; the least squares means being $36.2,159.9,230.8,287.0,359.7$, 425.5 and 471.4 pounds at birth, 6, 12, 18, 24, 30 and 36 months of age respectively. Male calves were heavier than females at all ages, and the weight at a given age was markedly affected by year and month of birth. Average weight at a given age changed little during the 15 years 1949 through 1963. Heritability of weight at the different ages was relatively low, being approximately 0.10 to 0.20 . Under present conditions mass selection for weight at one year of age would at best result in an approximate 12.8 pound increase per generation, or approximately 1.8 pounds per year. The expected genetic gain for weight at other ages was not appreciably different. For 54 animals, 51 males and 3 females, on which slaughter data were available, the average age at slaughter was 39.1 months while the mean weight was 512.1 pounds. The weight of the carcass accounted for only 41.6 percent of the live weight.

From the above analyses it was concluded that the ability of the N'Dama cattle to produce meat under Musaia conditions was rather limited. From reports of other studies $(9,12,20,21)$ it appears that the ability of the N'Dama to produce milk is also limited. It thus appears that the main asset of the N'Dama breed is its tolerance (28) to piroplasmoses, trypanosomiasis, and trypanosomes in general. Just how well the N'Dama would perform as a producer of meat and milk under more optimum feeding and management conditions is not really known; however, the work of Anliker (1), Montsma (20, 21) and O Korie et al. (24) indicates that under more optimum levels of feeding the performance of the N'Dama is not as good as that of most European breeds or the Santa Gertrudis. If crosses between N'Dama and European breeds possess some of the tolerance of the N'Dama to piroplasmoses, trypanosomiasis, and trypanosomes in general, N'Dama crossing schemes should be undertaken to develop cattle for Sierra Leone that are better producers of meat and milk. Plans for producing cheap but adequate feed, both concentrate and roughage, for the dry season should be developed simultaneously with the breeding scheme. 


\title{
630.7 \\ A STUDY OF THE N'DAMA CATTLE AT THE MUSAIA ANIMAL HUSBANDRY STATION IN SIERRA LEONE
}

\author{
R. W. TOUCHBERRY ${ }^{1}$
}

\section{Cattle Rearing in Sierra Leone}

T HE NAME N'Dama can be translated as "small cattle." The N'Dama cattle are described by Mason (19)* and by Joshi et al. (13) as a small, humpless, thick-set, dwarf breed. The head is short and broad with a straight profile, and the neck is of medium length and deep. From withers to tail setting the topline is flat and well muscled and is quite straight with a slight tendency to rise at the hind quarters. The rump has only a slight slope; the sacrum is not prominent; and the tail is long with a well developed switch. The ribs are well sprung and the musculature of the shoulders, back, and hind-quarters is rounded and well developed. The legs are short and fine boned. There is wide variation in color; fawn is the most common color, while buff, red, dun, black and mixtures occur less frequently. Horn size shows much variation but horns are generally long and lyre-shaped; polled animals do occur. Tolerance to trypanosomiasis and piroplasmoses, together with longevity, thriftiness in the dry season, and ability to endure the unhealthy conditions of the wet season are given as the main attributes of the breed. The top photograph on the cover depicts the general appearance of the N'Dama. All cattle in Sierra Leone are of the N'Dama breed.

A description of the size of the N'Dama in Sierra Leone, the French Sudan, and the Ivory Coast is given by Joshi et al. (13). Some weights and measurements of the N'Dama are listed in Table 1 along with weights and measurements of a sample of Holsteins in the University of Illinois dairy herd. No indication is given in the data on the N'Dama cattle of the number and ages of animals measured and weighed at the different stations. Further, it is not known what confounding effects of environment may exist at the different stations or between ages at the same station. In spite of these limitations it is obvious that the N'Dama is an extremely small breed as compared to the Holstein, but with the present data it cannot be determined how much of the difference in size of the N'Dama and Holstein is genetic.

${ }^{1}$ Professor of Genetics, Department of Dairy Science, University of Illinois, on assignment at Njala University College, Njala, Sierra Leone under the University of Illinois/USAID contract afe-132, June-July, 1965, and in cooperation with the Sierra Leone Ministry of Agriculture and Natural Resources (Agriculture Division).

* Numbers in parentheses refer to references listed on page 39. 
Table 1. - The Average Live Weights and Measurements of N'Dama Cattle and University of Illinois Holsteins

\begin{tabular}{|c|c|c|c|c|c|c|c|}
\hline \multirow[b]{2}{*}{ Characteristic } & \multirow[b]{2}{*}{ Source } & \multicolumn{3}{|c|}{ Males } & \multicolumn{3}{|c|}{ Females } \\
\hline & & $\begin{array}{c}1 \\
\text { year }\end{array}$ & $\begin{array}{c}2 \\
\text { years }\end{array}$ & $\begin{array}{l}\text { Matu- } \\
\text { rity }\end{array}$ & $\begin{array}{c}1 \\
\text { year }\end{array}$ & $\begin{array}{c}2 \\
\text { years }\end{array}$ & $\begin{array}{c}\text { Matu- } \\
\text { rity }\end{array}$ \\
\hline Live weight (kg.). & $\begin{array}{l}\text { (a) } \\
\text { (b) } \\
(\mathrm{c}) \\
\text { (d) }\end{array}$ & $\begin{array}{r}136 \\
181 \\
84 \\
\ldots\end{array}$ & $\begin{array}{l}220 \\
273 \\
300 \\
\ldots\end{array}$ & $\begin{array}{c}363 \\
414 \\
419 \\
\ldots\end{array}$ & $\begin{array}{r}138 \\
176 \\
81 \\
310\end{array}$ & $\begin{array}{l}151 \\
271 \\
234 \\
519\end{array}$ & $\begin{array}{l}238 \\
414 \\
353 \\
596^{\circ}\end{array}$ \\
\hline $\begin{array}{l}\text { Length from shoulder poin } \\
\text { to pinbone }(\mathrm{cm} .) \ldots \ldots\end{array}$ & $\begin{array}{ll} & \text { (a) } \\
\text { (b) } \\
\text { (d) }\end{array}$ & $\begin{array}{c}91 \\
96 \\
\ldots\end{array}$ & $\begin{array}{l}102 \\
115 \\
\ldots\end{array}$ & $\begin{array}{l}114 \\
126 \\
\ldots\end{array}$ & $\begin{array}{r}84 \\
95 \\
129\end{array}$ & $\begin{array}{r}91 \\
113 \\
151\end{array}$ & $\begin{array}{l}104 \\
124 \\
154^{\circ}\end{array}$ \\
\hline Height at withers $(\mathrm{cm}) .$. & $\begin{array}{l}\text { (a) } \\
\text { (b) } \\
\text { (c) } \\
\text { (d) }\end{array}$ & $\begin{array}{r}96 \\
85 \\
104 \\
\ldots\end{array}$ & $\begin{array}{r}107 \\
96 \\
106 \\
\ldots\end{array}$ & $\begin{array}{c}110 \\
108 \\
115 \\
\ldots\end{array}$ & $\begin{array}{r}96 \\
84 \\
94 \\
117\end{array}$ & $\begin{array}{r}102 \\
95 \\
109 \\
132\end{array}$ & $\begin{array}{l}106 \\
107 \\
112 \\
136^{\circ}\end{array}$ \\
\hline Heart girth (cm.). . & $\begin{array}{l}\text { (a) } \\
(\mathrm{o}) \\
\text { (d) }\end{array}$ & $\begin{array}{l}116 \\
142 \\
\ldots\end{array}$ & $\begin{array}{l}140 \\
156 \\
\ldots\end{array}$ & $\begin{array}{l}165 \\
173 \\
\ldots\end{array}$ & $\begin{array}{l}119 \\
122 \\
153\end{array}$ & $\begin{array}{l}125 \\
143 \\
188\end{array}$ & $\begin{array}{l}147 \\
164 \\
195^{\circ}\end{array}$ \\
\hline
\end{tabular}

a N'Dama cattle at the Musaia Animal Husbandry Station in Sierra Leone (13).

b N'Dama cattle at Bamako, French Sudan (25).

c N'Dama cattle at Mirankov, Ivory Coast (13).

d University of Illinois dairy herd (29).

e Four years of age.

It is believed that the N'Dama originated from cattle that accompanied Berber migrants from southern Morocco to the "Futa Jallon" plateau in French Guinea (13). The N'Dama has since spread to the surrounding areas and has interbred with the Zebu cattle of the subsaharan savannahs and the small shorthorned cattle of the coastal areas. Doutressoulle (6) reported that the N'Dama increased rapidly in the periods following the rinderpest epizootics of 1890-91 and 1918. At these times the N'Dama replaced herds of other types in Senegal and the French Sudan which had been decimated by rinderpest.

The N'Dama cattle are found in a belt approximately parallel to the equator and stretching from the Atlantic coast in Senegal and Guinea to the Borgou district in northern Dahomey. The northern and southern limits are approximately at latitudes $14^{\circ} \mathrm{N}$ and $8^{\circ} \mathrm{N}$. The northern limit is closely aligned with that of the tsetse fly area, and, consequently, with the southern limit of the Zebu cattle of the more open country to the north.

A number of widely different estimates have been given for the cattle population in Sierra Leone ranging from 250,000 to 400,000 head. No reliable estimate is available because no census of the cattle population has been made in Sierra Leone and because there is a constant migration of cattle in and out of Sierra Leone across the Guinea border 
along the north and northeast boundaries. A conservative estimate for the cattle population of Sierra Leone, based on generalized estimates made by government officials, agricultural officers, and veterinarians, is that there are approximately 250,000 head of cattle in Sierra Leone with approximately 150,000 in the principal cattle raising area, the Koinadugu district in the northern province of Sierra Leone (26).

Three tribes inhabit the Koinadugu district: the Yalunkas in the north, the Kurankos in the south and southwest, and the Limbas in the west and southwest (22). The Yalunkas are along and north of the Mongo River, the Kurankos are along the Seli and Bagbe rivers, and the Limbas are south of the Mongo and west of the Seli. The Fula cattle owner is mainly found in Yalunka country, while a few are in Kuranko and Limba country.

Cattle production in Sierra Leone is plagued with many diseases and pests. Diseases such as anthrax, rinderpest, contagious bovine pleuropneumonia, blackquarter, red water fever, hemorrhagic-septicemia, calf diphtheria, brucella abortus, and trypanosomiasis are said to be widespread. Ticks, liver flukes, and worms are prevalent. Further, there are a number of predators such as leopards and pythons that prey on the younger animals.

Currently there are neither adequate data nor unequivocal information about the true state of affairs concerning cattle disease and parasite infections among the N'Dama cattle in Sierra Leone. Most animal husbandmen and veterinarians in Sierra Leone say that diseases and parasites are widespread; but the actual incidence, the importance of the several infections, and how such infections influence the economy of cattle raising remain largely a matter for further investigation and appraisal. A rather general survey (23) of animal diseases in Africa was published in 1965 by the National Academy of Sciences National Research Council.

The cattle must endure serious feed shortages in the dry season and late rainy season. The year is divided into a rainy season, April through October, and a dry season, November through March. The harmattan, a dry northeast wind, can be expected from December through February. There is no storage of feed during the period when the vegetation is succulent, nutritious, and plentiful; thus, the cattle have to endure the late rainy season on old, lower-quality vegetation and the dry season on a limited supply of vegetation. Mature animals at the Musaia station have lost as much as 200 pounds during the dry season, and some young animals have weighed no more at 18 months than at 6 months after having been weaned at 9 months and enduring a dry season on their own. 
The vegetation is derived guinea savannah with fire-resistant tree species. There are patches of high forest along the river banks and in isolated pockets on steep hillsides that have avoided the main bush fires. The main grass species are Chasmopodium caudatum, Hyparrhenis spp., Pennisetum subangustum, and Andropogan gabonensis.

According to Faulkner and Brown (7), probably the most serious limitations besetting cattle production in this area are the result of the social and nomadic practices of the Fula cattle owners. Murray (22) has given a general description of the Fula cattle owners of Sierra Leone, their cattle, and their methods of management. The Fula cattle owners of Sierra Leone consist of nomadic Futa, Teliko, Kebu, and Boway Fulas. They move in groups from one area to another in search of fresh grazing and water for their cattle. They stay in one area from two to three years after which they move their camp, starting the cycle anew approximately every 20 years. All Fula cattle owners practice arable farming on a larger scale than the local tribes. Rice, cassava, millet, and maize are the main crops; however, the Fulas do not produce or store feed for cattle for the dry season. The customary practice is to burn areas of brush and grass in successive stages to produce feed for cattle for the dry season. Burning begins with the end of the rains and ends only with the arrival of the rainy season. It is a curious fact that even after a prolonged dry season, burning off the old grass results in new grass growth (26).

Cattle are a Fula's capital and wealth, and the relative wealth is in general measured by the total number of cattle owned. Considering all the obstacles that confront cattle raising in Sierra Leone, Roche (26) concludes that the Fula is an excellent stockman and that many of his practices are based on sound common sense. For many years the Fulas have used a mixture of termite earth and loose salt to provide the necessary salt for their cattle. The Fula knows good animals and is hesitant to sell good females. He is always ready to sell males that are not needed, if he can obtain a reasonable price. Further he sells the females that do not produce calves or that appear unable to raise good calves.

After the excess males and unproductive females are sold, the remaining animals in a Fula's herd are allowed to mate randomly. By selling the unproductive females, the Fula is fostering some selection for female productivity. The Fulas are often placed in a disadvantageous position, however, since Freetown is in general over-supplied with cattle and there is no alternative in Freetown but to sell their animals to the local butchers. There is an urgent need for the establishment of an equitable cattle marketing system. 
In 1952 the government of Sierra Leone began developing a plan for settling the cattle owners (22). This plan has been implemented and is being met with reasonable success. If the cattle owners are settled, it should be easier to establish better health, feeding, breeding, and other husbandry and management practices. The cattle settlement scheme should also help establish a dependable cattle market for the Fula cattlemen and a regular supply of meat for markets of the population centers, such as Freetown.

\section{The Musaia Animal Husbandry Station}

Soon after World War II plans were initiated for establishing an animal husbandry station near Musaia, in the Koinadugu district of northern Sierra Leone. The Musaia area has a dense cattle population. Work was begun in 1946 on establishing the station; by 1948 the station was completed, and cattle were moved there from the Teko Veterinary Station.

The mean annual temperature at Musaia is approximately $26.0^{\circ} \mathrm{C}$. with a mean low in December and January of $24.4^{\circ} \mathrm{C}$. and a mean high in March and April of $28.5^{\circ} \mathrm{C}$. The mean annual relative humidity is approximately 82 percent, with a mean low of approximately 76 percent in February and a mean high of approximately 89 percent in September. Of more importance to the cattle industry is the annual rainfall, the distribution of which is shown in Table 2 for 1952 through 1964. December, January, and February are definitely dry months, while March has an average rainfall of only 1.4 inches, which is not enough to initiate growth of grass. With a definite dry season and no storage of feed the cattle must endure rather rigorous conditions for 4 or 5 months of the year.

The station has an area of approximately 2,500 acres, is enclosed in a well-built barbed wire fence, and is divided into blocks of approximately 200 acres, each set off by sturdy barbed wire fences; there are a number of smaller pastures. The topography is hilly: the valleys at the Musaia station are 1,000 to 1,500 feet above sea level, while the hills rise 2,500 to 3,000 feet above sea level.

The station was established to serve as a research station and as a vehicle for demonstrating good animal husbandry practices. There is evidence that in its relatively short life the station has had a marked effect on the Fula cattle owners. Gamotox and Phenothiazine have been distributed by the station to cattle owners, and station personnel have demonstrated the use of bloodless castrators $(22,26)$. After having seen the better grazing afforded by pangola grass on the lowlands and 


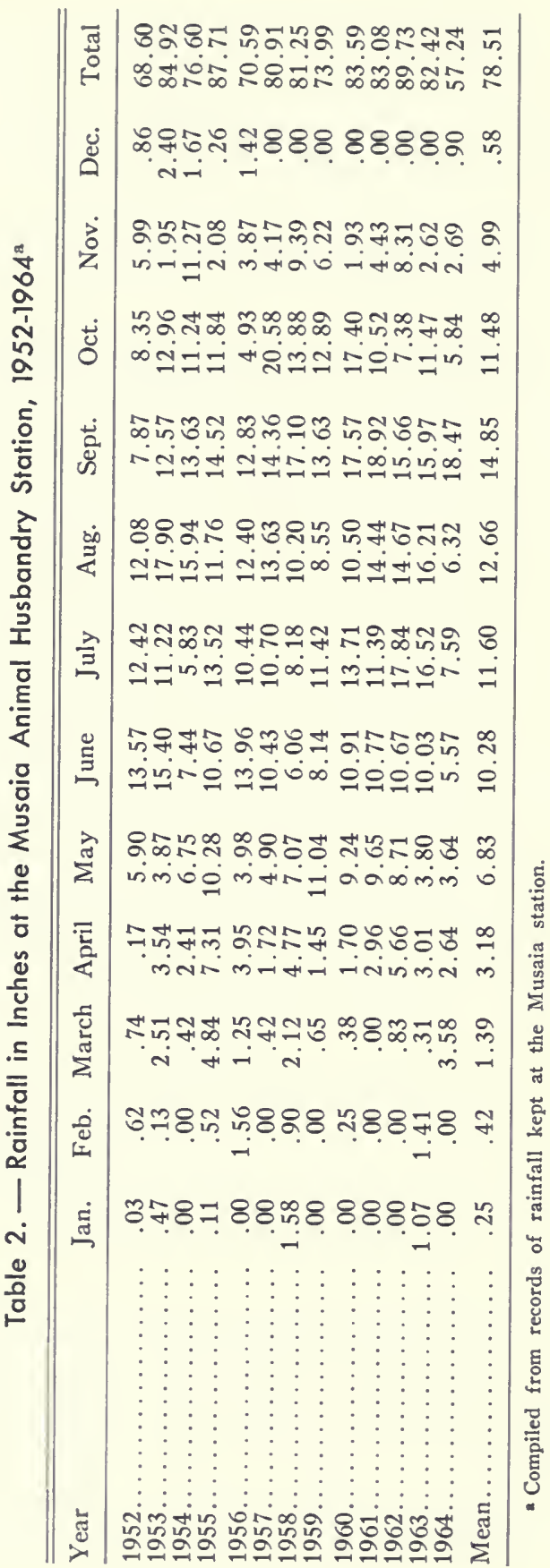


Pueraria and Stylosanthes on the uplands at the Musaia station, the Fulas have shown interest in acquiring better grazing (26).

In its role as a research institution, the station set out in 1548 to determine the possibilities for milk production and beef prodution using N'Dama cattle. As a consequence, a milking herd and a beef lerd were established (12). Prior to this, in the early 1940's, a milking hrd had been established at the Teko station to investigate problems connected with milk production (12). The 55 animals in this herd were transferred to Musaia in 1948, and these animals constituted the milk herd; shown in Table 3 are the average milk production figures for this herd. It was indicated in the Jones report (12) that milk from N'Dama cows had an average butterfat test of from 6.5 to 7 percent.

\section{Table 3. - Milk Production of N'Dama Cattle at the Musaia Animal Husbandry Station in Sierra Leone ${ }^{\mathrm{a}}$}

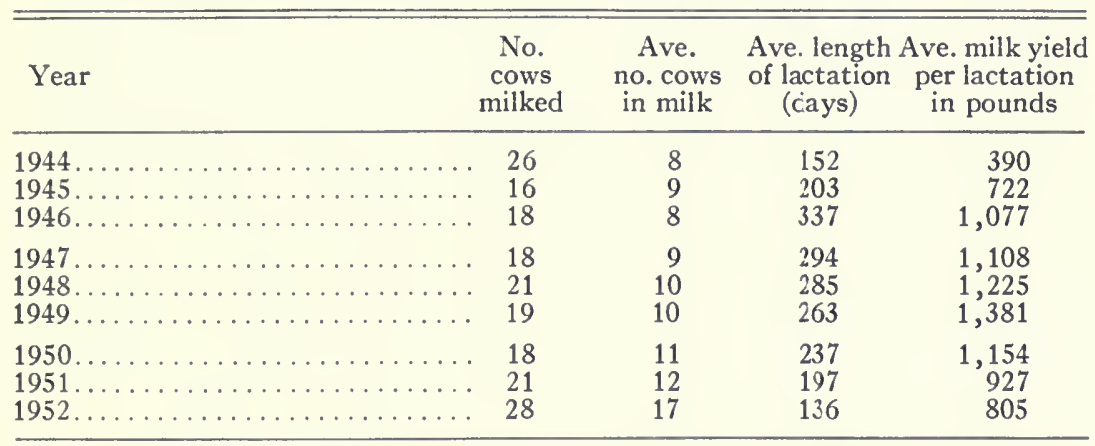

a These data were taken from a report submitted in 1953 by $T$. S. Jones to the Ministry of Agriculture of Sierra Leone (12). For the years 1944-1947 the cows vere at the Teko station, and were moved in early 1948 to the Musaia station.

In general, milk production was low; cow 33 produced 2,521 pounds in 210 days and cow 37 produced 2,516 pounds in 322 days for two of the highest lactation yields. When suckling was not allowed at the start of milking, there was difficulty in getting cows to let down their milk. During part of the dry period supplemental feeding with concentrate gave some increases in milk yield. In 1953 the milking herd was discontinued as such because of low milk production, and the cows were made a part of the beef herd. The average 305-day lactation yield (4) of the 74,001 cows on DHIA test in Illinois in 1964-65 was 11,911 pounds of milk and 458 pounds of butterfat and is quoted here as a bench mark to help the reader understand that the milk production of the Musaia herd was low. 
The numbers of animals in the milk and beef herds from 1948 to 1953 :re shown below.

$\begin{array}{cccc}\text { Year } & \text { Dairy } & \text { Beef } & \text { Total } \\ 1948 & 48 & 9 & 57 \\ 1949 & 53 & 52 & 105 \\ 1950 & 59 & 60 & 119 \\ 1951 & 79 & 77 & 156 \\ 1952 & 130 & 99 & 229 \\ 1953 & \ldots & 219 & 219\end{array}$

Of the 219 animals in 1953, there were 104 cows, 53 heifers, 55 bulls and bull calves, and 7 oxen. By the summer of 1965 the herd contained approximately 550 animals, approximately half of which were cows.

\section{The Beef Herd}

The beef herd is kept in groups of approximately 25 cows each; in 1965 there were approximately ten such groups. One man is assigned to each of the ten groups, and he is directly responsible for the care, health, and well being of the cattle in his group. These men are astute cattlemen, generally Fulas, and they literally live with their cattle (26).

There is a second labor force of approximately 60 men concerned with building fences, preparing land for seeding improved pastures, weighing cattle, helping treat cattle for worms and ticks, and aiding in the routine vaccination for anthrax, rinderpest, hemorrhagic septicemia, and blackquarter. During the periods of clearing land for new pastures as many as 200 men may work with this second labor force.

The calves are weaned at approximately 8 to 9 months of age, and the bull and heifer calves are separated and kept in heifer and bull pastures. There are usually three bull and three heifer pastures so that young animals of widely differing ages are not kept together. The heifers are bred so as to calve for the first time at approximately 3 years of age. The bull calves are kept until they are approximately 3 years old, at which time the larger ones are chosen and kept for future sires, and the smaller ones are slaughtered and sold for meat. Many of the definitely inferior bull calves are disposed of prior to 3 years of age.

In general there is no supplemental feeding during the dry season; however, the Jones report (12) indicates that in the most severe drouth years there was some supplemental feeding of a grain mixture. In other years silage was made on an experimental basis, but the cattle were most reluctant to eat the silage even though pasture was very limited and salt and molasses were added to the silage (26).

The cattle at the Musaia station are watched closely by the Fula herdsmen, are given excellent medical care, have ample grazing most of 
the year, and are protected from worms, ticks, and wild aninals. Except for the shortage of feed in the dry season the husbandr? is good.

\section{Age at first calving}

Shown in Table 4 are the ages at first calving for the N'Tama cattle in the various families. The average age at first calving for 11 families was 39.4 months. The lowest age at first calving was 33.2 months for the $\mathrm{R}$ family while the highest was 48.0 for the $\mathrm{J}$ family For those cows that calved, the average number of calves per cow was 3.69. The average age at first calving has been reported $(10,13)$ as $4 . .5$ and 36 to 42 months, respectively. The average age at first calving for dairy cattle in the United States is 24 to 27 months. At present, beef cattle under western range conditions are being bred to calve at 2 yeas of age.

\section{Sex ratio}

In Table 4 it is shown that of 1,269 calves born to 34 cows, 561 were males, 601 were females, and the sex of 107 was no designated. Thus of 1,162 calves, 48.3 percent were males and 51.7 percent were females. This sex ratio does not differ significantly from a 50-50 ratio $\left(x^{2}=1.38,1\right.$ d.f. $)$. Of 1,234 calves born in the Universit? of Illinois

\section{Table 4. - Age at First Calving, Number of Calves, and Sex Ratio by Families}

\begin{tabular}{|c|c|c|c|c|c|c|c|c|}
\hline Family & $\begin{array}{l}\text { No. cows } \\
\text { calving } \\
\text { (age known) }\end{array}$ & $\begin{array}{l}\text { Age at first } \\
\text { calving } \\
\text { (months) }\end{array}$ & $\begin{array}{c}\text { Total no. } \\
\text { cows } \\
\text { calving }\end{array}$ & $\begin{array}{l}\text { No. } \\
\text { calves }\end{array}$ & $\begin{array}{c}\text { No. } \\
\text { male } \\
\text { calves }\end{array}$ & $\begin{array}{l}\text { No. } \\
\text { female } \\
\text { calves }\end{array}$ & $\begin{array}{l}\text { No. of } \\
\text { unknown } \\
\text { sex }^{\circ}\end{array}$ & $\begin{array}{l}\text { No. calves } \\
\text { per cow } \\
\text { calving }\end{array}$ \\
\hline Main. & $\ldots 46$ & 39.3 & 125 & 508 & 207 & 229 & 72 & 4.06 \\
\hline & $\ldots \quad 25$ & 40.6 & 60 & 285 & 133 & 121 & 31 & 4.75 \\
\hline A. & $\ldots$ & 42.3 & 4 & 16 & 7 & 8 & 1 & 4.00 \\
\hline C. & 10 & 39.7 & 10 & 53 & 20 & 33 & 0 & 5.30 \\
\hline $\mathrm{D}$. & $\begin{array}{ll}\ldots & 11\end{array}$ & 35.3 & 11 & 41 & 19 & 21 & 1 & 3.72 \\
\hline E. & $\ldots$ & 44.2 & 6 & 30 & 14 & 16 & 0 & 5.00 \\
\hline $\mathrm{G}$. & . & 34.7 & 3 & 16 & 10 & 6 & 0 & 5.33 \\
\hline $\mathrm{H} \ldots$ & $\ldots$ & 45.2 & 11 & 48 & 17 & 31 & 0 & 4.67 \\
\hline J.. & $\cdots$ & 48.0 & 9 & 33 & 16 & 17 & 0 & 3.67 \\
\hline $\mathrm{K}$. & . 45 & 38.1 & 45 & 104 & 51 & 51 & 2 & 2.31 \\
\hline L. & 7 & 41.7 & 7 & 25 & 12 & 13 & 0 & 3.57 \\
\hline M. & $\ldots$ & 45.7 & 7 & 23 & 15 & 8 & 0 & 3.29 \\
\hline N. & $\ldots$ & 38.8 & 8 & 19 & 8 & 11 & 0 & 2.38 \\
\hline R.... & $\ldots \quad 22$ & 33.2 & 22 & 40 & 20 & 20 & 0 & 1.82 \\
\hline & 7 & 37.4 & 5 & 5 & 1 & 4 & 0 & 1.00 \\
\hline $\mathrm{T}$ & 5 & 34.6 & 5 & 5 & 3 & 2 & 0 & 1.00 \\
\hline U... & 6 & 44.8 & 6 & 18 & 8 & 10 & 0 & 3.00 \\
\hline Total. & $\ldots 231$ & 39.4 & 344 & 1,269 & 561 & 601 & 107 & 3.69 \\
\hline
\end{tabular}

a The birth dates of many cows in the original Main and B families were not known; thus some ages at first calving were not known.

b Even though age at first calving was not known, the sex of the newborn calves was recorded; thus the discrepancy between columns 2 and 4 .

In the early years the sex of some calves was not recorded. 
dairy catle crossbreeding herd, 642 or 52 percent were males and 592 or 48 pecent were females (16). This sex ratio was not significantly different from a 50-50 ratio $\left(\chi^{2}=2.03,1\right.$ d.f. $)$. Further, a chi square test indiated that the two sex ratios were not significantly different $\left(x^{2}=3.3,1\right.$ d.f.); however, in most European breeds there are more males thar females at birth.

\section{Calving interval}

Shown lelow is the distribution of calving intervals.

$\begin{array}{lccccc}\begin{array}{c}\text { Intervals } \\ \text { in days }\end{array} & \begin{array}{c}\text { No. cows } \\ \text { calving }\end{array} & \begin{array}{c}\text { Intervals } \\ \text { in days }\end{array} & \begin{array}{c}\text { No. cows } \\ \text { calving }\end{array} & \begin{array}{c}\text { Intervals } \\ \text { in days }\end{array} & \begin{array}{c}\text { No. cows } \\ \text { calving }\end{array} \\ 299 \text { or less } & 14 & 420-449 & 53 & 570-599 & 30 \\ 300-329 & 64 & 450-479 & 42 & 600-629 & 36 \\ 330-359 & 151 & 480-509 & 37 & 630-659 & 21 \\ 360-389 & 184 & 510-539 & 38 & 660-689 & 19 \\ 390-419 & 106 & 540-569 & 52 & \begin{array}{l}690 \text { or } \\ \text { greater }\end{array} & 79\end{array}$

The mein calving interval was 467 days, which is high compared with the mean calving interval for both beef and dairy cattle in the United Staes (approximately 13 months or 390-400 days). The calving intervals for the Musaia N'Dama ranged from one of 267 days for cow 153 to one of 1,062 days for cow D17. In general the calving interval was approzimately two months longer than that for European breeds and slightly shorter than that reported for Zebu breeds. The mean square associated with variation between cows was 21,635 , while that associated vith variation between intervals of the same cow was 25,001 ; the degrees of freedom were 262 and 663 respectively. This finding is similar to results generally found for European breeds.

\section{Age at disposal and of animals in the herd}

The average age at disposal for males was 29.0 months while that of females was 32.4 months (Table 5). For many of the younger families the average age at disposal is quite low. This reflects the fact that most animals in these sire families were born rather recently. This can also be seen from the average age of live animals in these families.

The average ages of live animals in the herd were 22.3 and 46.2 months for males and females respectively. The females in dairy and beef herds in the United States have an average age of approximately 60 months; thu;, 46.2 months is low for the average age of females. On the other hand 22.3 months is much higher than the average age of males in herds in the United States, as most male cattle, both dairy and beef, are sold for meat by 15 months of age. 
Table 5. - The Average Age in Months of Males and Females in the Herd and at Disposal or Death

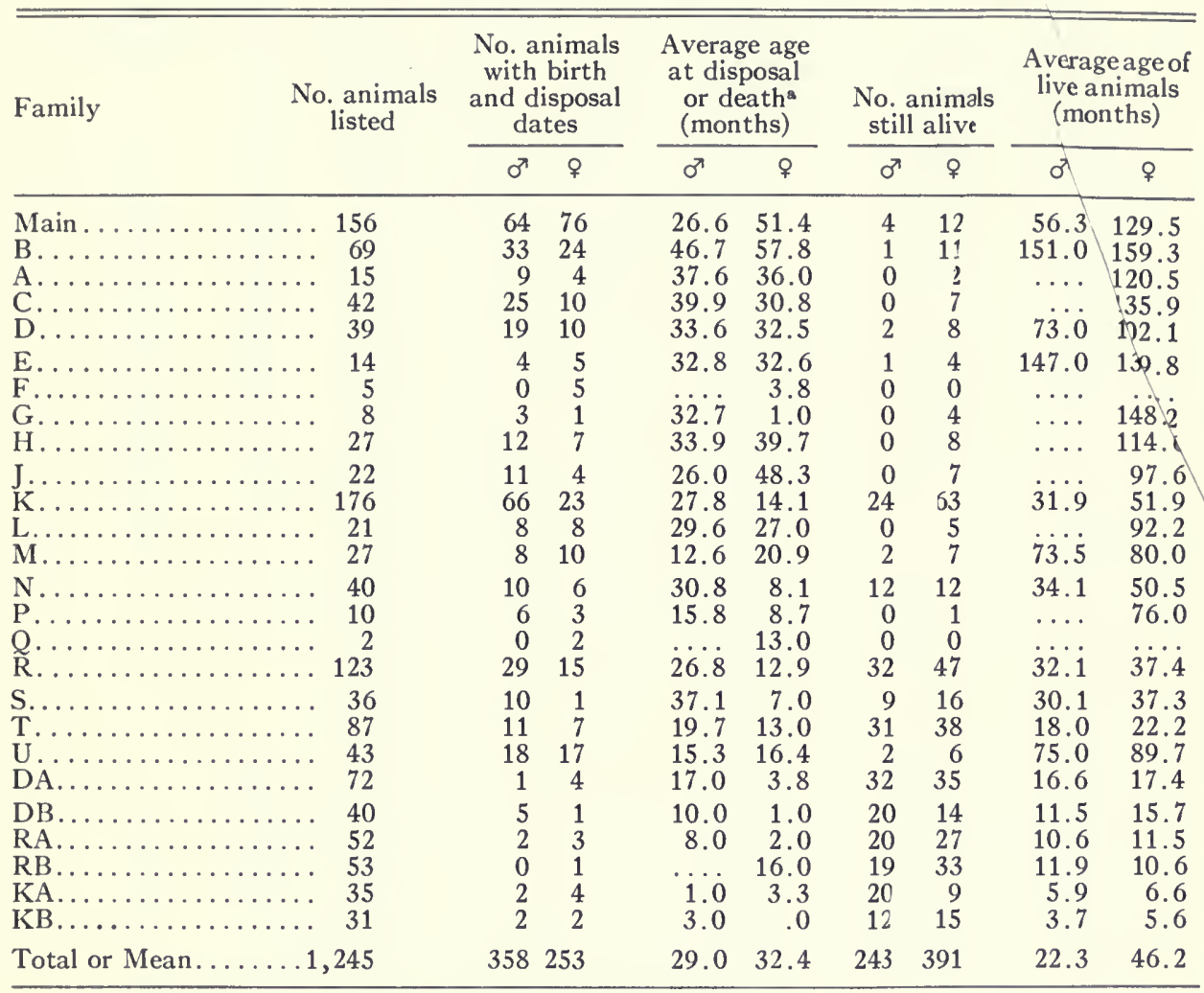

a Includes all animals on which age at death or disposal was known.

\section{Death losses}

Of the 1,245 animals listed in Table 5, 87 died before 2 years of age, 52 were sold or culled, and 13 were reported missing and presumably lost to predators. Thus, by 2 years of age, 152 animals or 12.2 percent were not available for breeding purposes. This is comparable to losses from similar causes in the United States (5). No record of losses because of failure to breed was available. The losses from death and culling appeared to be randomly distributed according to families and sex.

\section{Body weights}

All animals in the beef herd were weighed at birth and on the first day of the month for as long as they lived. Shown in Table 6 are the numbers of progeny in the 26-sire progeny groups on which weights were available and thus included in the weight data analysed. The first 
Table 6. - The Number of Progeny in the Sire Groups at Various Ages ${ }^{\mathrm{a}}$

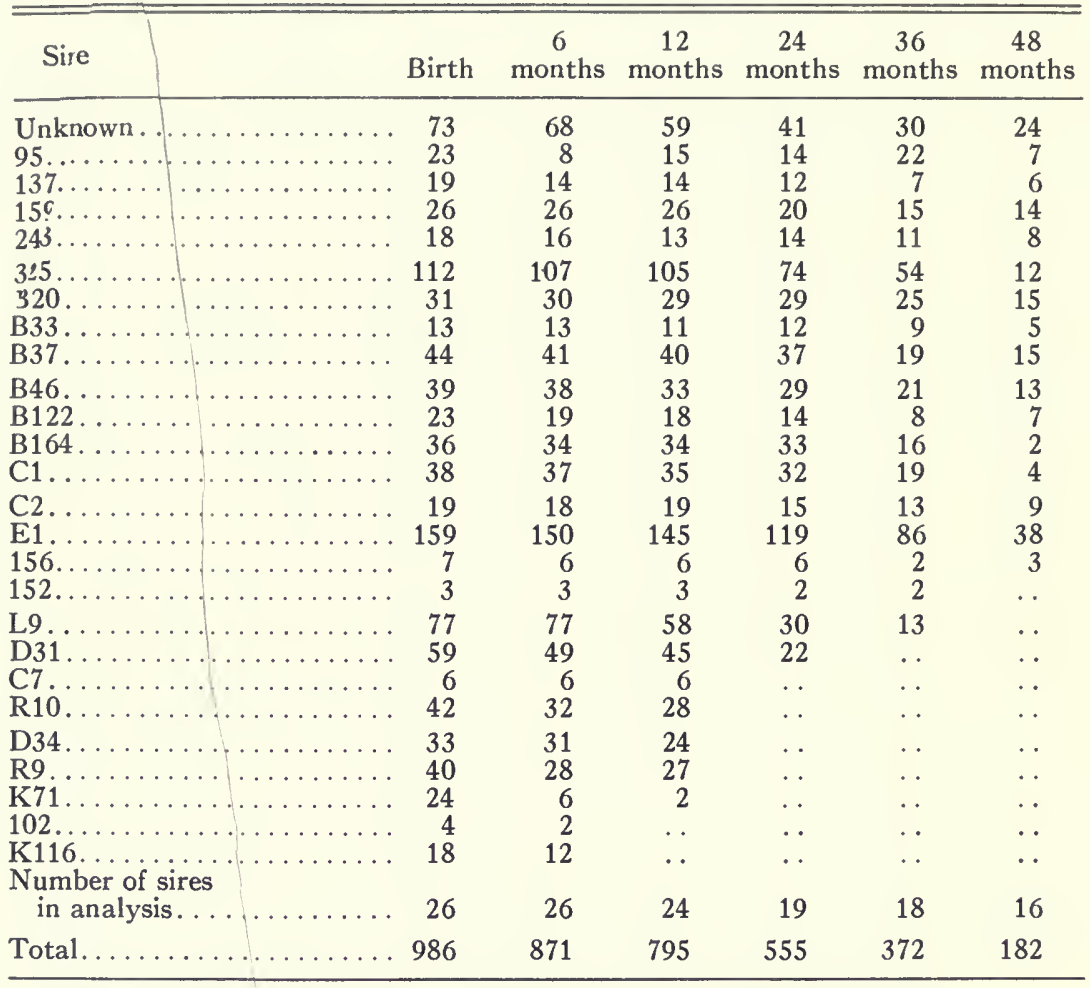

a These numbers include only those animals for which weights were available.

group, labeled unknown, is composed of progeny whose sires were not known. There are a number of blanks in the lower right hand corner of the table because the progeny of these sires were born recently and have not reached the older ages. Further, many of the sires near the bottom of the table have many more progeny, but which were too young to have weights beyond birth and 3 or 4 months, and thus were not included at all. The figures in Table 6 cannot be used as a means of comparing the viability of calves of the different sires, as many calves were not old enough to have weights at the older ages.

Shown in Tables 7 and 8 are the numbers born in the different years, in the different months of the year, and of the two sexes. Again, these figures cannot be used as a means of comparing the relative viability of calves born in the different months or different years unless those too young to have weights at the older ages are deleted. By observing the numbers born in the different years it is apparent that the number in the 
Table 7. - The Numbers of Calves Born in Different Years ${ }^{\mathrm{a}}$

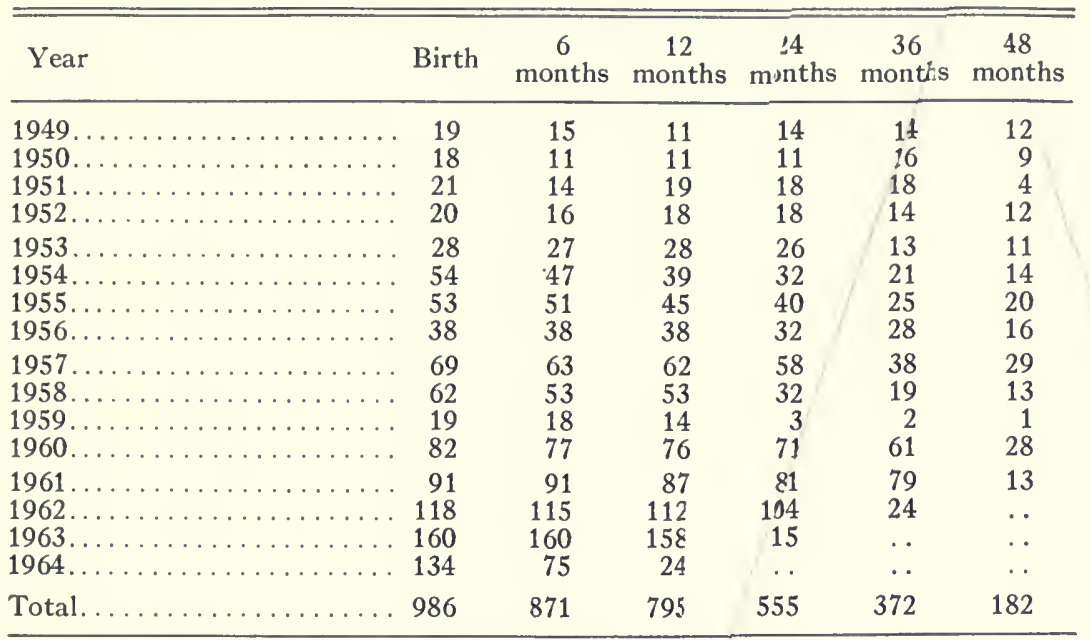

a The numbers include only those animals for which weights were available.

Table 8. - The Numbers of Calves Born in Different Months of the Year and of the Two Sexes ${ }^{a}$

\begin{tabular}{|c|c|c|c|c|c|c|}
\hline & Birth & $\begin{array}{c}6 \\
\text { months }\end{array}$ & $\frac{12}{\text { months }}$ & $\begin{array}{c}24 \\
\text { months }\end{array}$ & $\begin{array}{c}36 \\
\text { months }\end{array}$ & $\begin{array}{c}48 \\
\text { months }\end{array}$ \\
\hline \multicolumn{7}{|l|}{ Month of birth } \\
\hline 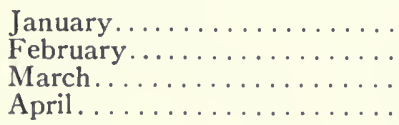 & $\begin{array}{r}114 \\
86 \\
40 \\
48\end{array}$ & $\begin{array}{r}106 \\
73 \\
40 \\
46\end{array}$ & $\begin{array}{r}107 \\
81 \\
34 \\
41\end{array}$ & $\begin{array}{l}80 \\
63 \\
26 \\
33\end{array}$ & $\begin{array}{l}60 \\
50 \\
21 \\
21\end{array}$ & $\begin{array}{l}24 \\
20 \\
16 \\
13\end{array}$ \\
\hline 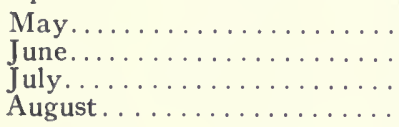 & $\begin{array}{r}115 \\
34 \\
13 \\
76\end{array}$ & $\begin{array}{r}100 \\
28 \\
11 \\
72\end{array}$ & $\begin{array}{l}93 \\
23 \\
10 \\
50\end{array}$ & $\begin{array}{r}78 \\
20 \\
9 \\
26\end{array}$ & $\begin{array}{r}60 \\
15 \\
6 \\
13\end{array}$ & $\begin{array}{r}37 \\
10 \\
4 \\
4\end{array}$ \\
\hline $\begin{array}{l}\text { September } \ldots \ldots \ldots \ldots \ldots \\
\text { October } \ldots \ldots \ldots \ldots \ldots \\
\text { November } \ldots \ldots \ldots \ldots \ldots \ldots \\
\text { December. } \ldots \ldots \ldots \ldots \ldots \ldots\end{array}$ & $\begin{array}{l}102 \\
120 \\
111 \\
127\end{array}$ & $\begin{array}{r}90 \\
94 \\
93 \\
118\end{array}$ & $\begin{array}{r}75 \\
82 \\
85 \\
114\end{array}$ & $\begin{array}{l}38 \\
38 \\
54 \\
90\end{array}$ & $\begin{array}{l}21 \\
19 \\
35 \\
51\end{array}$ & $\begin{array}{r}5 \\
11 \\
13 \\
25\end{array}$ \\
\hline 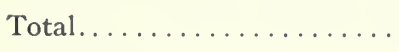 & 986 & 871 & 795 & 555 & 372 & 182 \\
\hline $\begin{array}{l}\text { Sex of calf } \\
\text { Male } \ldots \ldots \ldots \ldots \ldots \ldots \ldots \ldots \\
\text { Female } \ldots \ldots \ldots \ldots \ldots \ldots\end{array}$ & $\begin{array}{l}478 \\
508\end{array}$ & $\begin{array}{l}435 \\
436\end{array}$ & $\begin{array}{l}392 \\
403\end{array}$ & $\begin{array}{l}278 \\
277\end{array}$ & $\begin{array}{l}165 \\
207\end{array}$ & $\begin{array}{r}36 \\
146\end{array}$ \\
\hline Total..... & 986 & 871 & 795 & 555 & 372 & 182 \\
\hline
\end{tabular}

a The numbers include only those animals for which weights were available. 
herd had increase approximately eightfold from 1950 to 1964. The figure for 1964 doe not include all those born in 1964, as those born in late 1964 would have, had only birth weights and 2 or 3 month weights recorded at the time the data were copied.

From Table 8 it apparent that the majority of the cows calve in September, October, November, December, January, and February. In these 6 months, 660 of the 986 animals were born. The figures for the months of November and December are lower than they would be if all calves born late in 1964 had been included. The unexpectedly high number $0^{-}$births occurring in May is probably the result of a management prastice (12) instigated in the early fifties whereby an attempt was made to breed cows to deliver at the beginning of the wet season. This practice was abandoned after a few years. Most of the Fula cattlemen have their cows calve during the period from September through February and mainly in December, January, and February.

The numbers of males and females at the different ages as shown in Table 8 afford an interesting bit of information. The numbers of males and females do not differ significantly until 36 months of age. At the Musaia station, males are generally kept until 3 years of age before they are slaughtered or used as sires. It appears that most N'Dama in Africa are not slaughtered until after they reach 3 years of age $(10,11,24)$. It is after 3 years of age that most of the culling of unwanted males occurs; thus, not until 4 years of age does the number of females greatly exceed the number of males.

Tables 6,7 , and 8 provide another bit of interesting information. Even though there are 986 calves with birth weights, there are only 182 with weights at 48 months of age. To accumulate a large volume of data on cattle at older ages requires that a large herd be kept for many years.

To describe the weights of the animals, linear model I was used.

$$
\text { I. } Y_{i j k l m}=U+B_{i}+A_{j}+M_{k}+S_{1}+E_{i j k l m}
$$

$Y_{1 j k l m}$ is the weight at a given age of the $m^{\text {th }}$ calf, of the $1^{\text {th }}$ sex, born in the $\mathrm{k}^{\text {th }}$ month of the $\mathrm{j}^{\text {th }}$ year and by the $\mathrm{i}^{\text {th }}$ sire.

$\mathrm{U}$ is the least squares mean.

$B_{i}$ is the random deviation associated with the progeny of the $i^{\text {th }}$ sire.

$A_{f}$ is the fixed effect associated with calves born in the $j^{\text {th }}$ year.

$M_{k}$ is the fixed effect assocated with calves born in the $k^{\text {th }}$ month of the year.

$S_{1}$ is the fixed effect associated with calves of the $1^{\text {th }}$ sex.

$\mathrm{E}_{1 \mathrm{fklm}}$ is the random deviation associated with the $\mathrm{m}^{\text {th }}$ calf of the $1^{\text {th }}$ sex, born in the $k^{\text {th }}$ month of the $\mathrm{j}^{\text {th }}$ year and by the $\mathrm{i}^{\text {th }}$ sire. 
Table 9. - The Analyses of Variance of Weight at Ten Different Ages

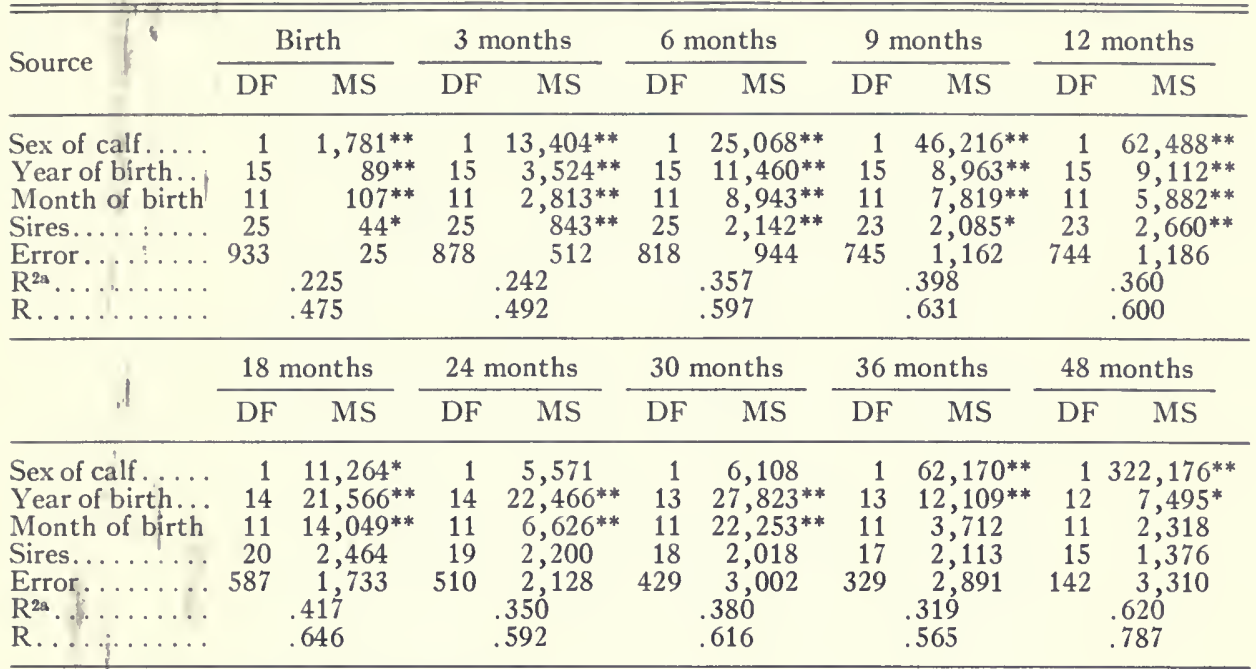

* Significant at the .05 level of probability.

* Significant at the 01 level of probability.

a $\mathrm{R}^{2}=$ Fraction of variance accounted for by model 1 (exclusive of error).

Shown in Table 9 are the least squares analyses of variance for weight at ten different ages. As can be seen from the $\mathrm{R}^{2}$ values in the next to last row of Table 9, model I has accounted for 22.5 to 62.0 percent of the variance in weight at the different ages. The $\mathrm{R}^{2}$ value at 48 months of age is markedly higher than those at the younger ages and is probably a result of the severe culling of males between 36 and 48 months on the basis of weight. This culling has brought about an extremely large difference between males and females at 48 months and thus an extremely large mean square for sex. The $\mathrm{R}$ values, which are the correlations between actual weights and weights as predicted by model I, range from 0.475 to 0.787 ; thus model I has been effective in explaining variations in weight at the various ages.

The least squares constants for sex of calf and month of birth are shown in Table 10 along with the least squares means, while the least squares constants for year of birth are listed in Table 11. These constants are useful in finding the means of various categories. For example, the mean birth weight of all male calves is $36.2+1.4=37.6$ pounds while that for all female calves is $36.2-1.4=34.8$ pounds. Males are $1.4-(-1.4)=2.8$ pounds heavier at birth than females. One further quality of the least squares means and constants for males and females is that they have been adjusted for the fixed effects of 


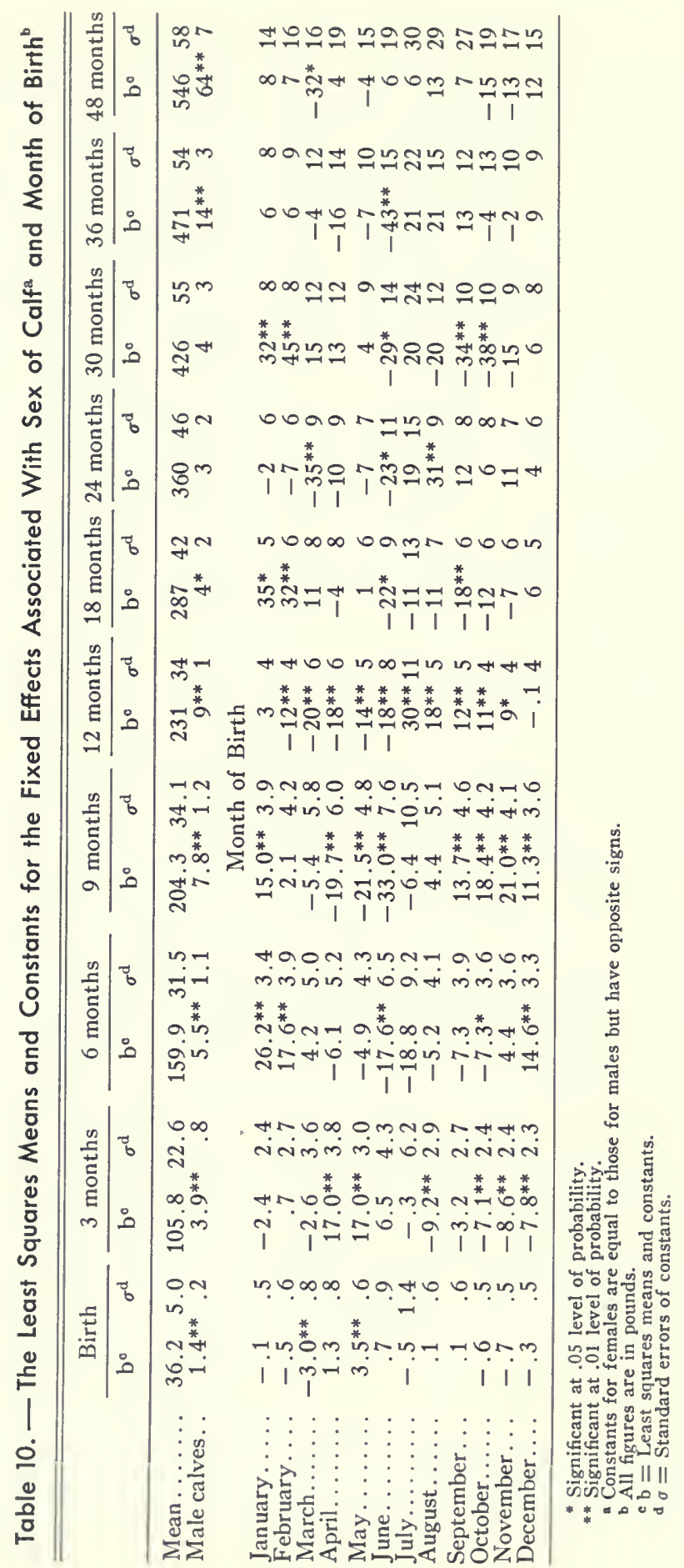




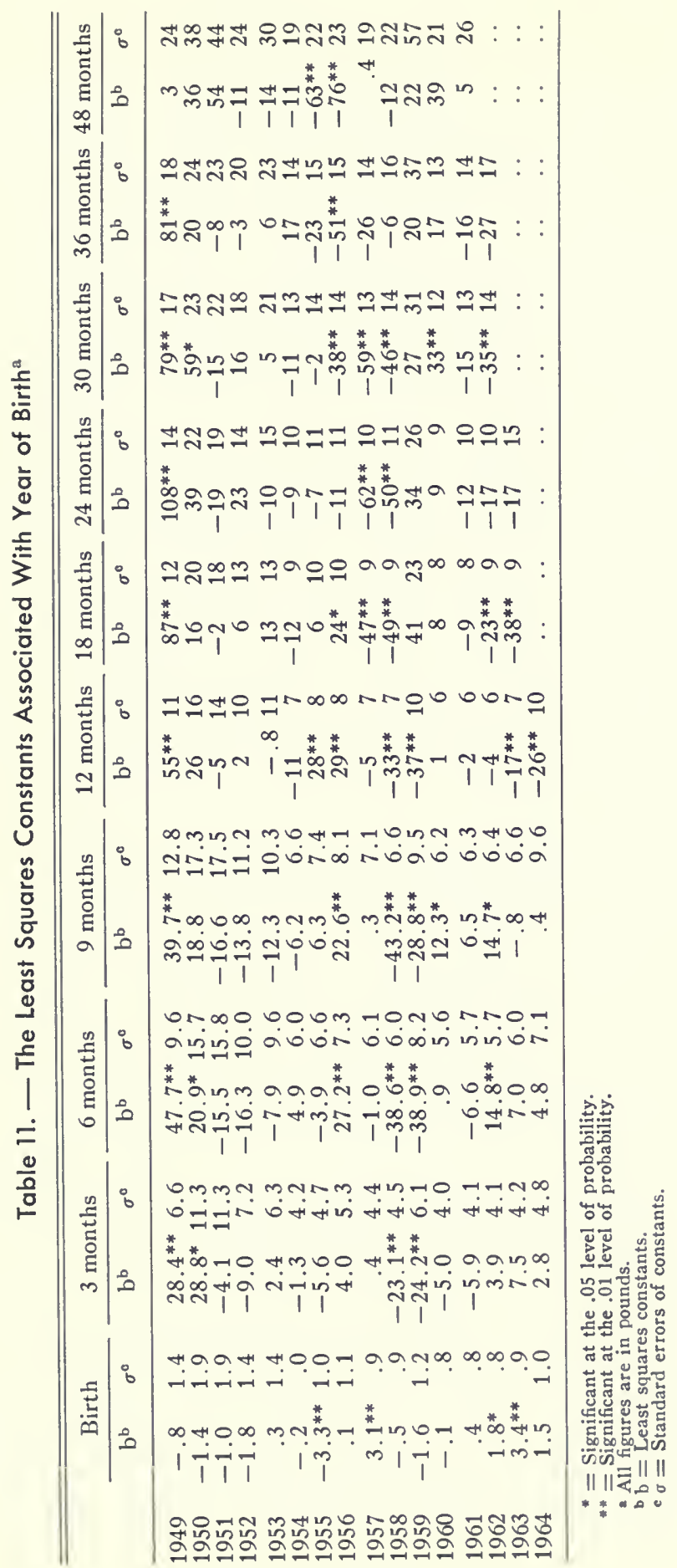


month and year of birth and the sampling variation between sires. The mean birth weight of calves born in 1957 was $36.2+3.1=39.3$ pounds while that of calves born in 1955 was $36.2-3.3=32.9$ pounds. Those born in 1957 were $39.3-32.9=3.1-(-3.3)=6.4$ pounds heavier than those born in 1955. The differences between year of birth have been adjusted for the fixed effects of month of birth and sex of calf and the random variation associated with sires. The least squares means and constants in Tables 10 and 11 can be used to find the adjusted means of a variety of subclasses. For example, the mean birth weight of male calves born in January of 1957 is $36.2+1.4+(-0.1)+3.1$ $=40.6$ pounds.

As indicated in Table 9, the effects associated with sex of calf were significant at all ages except 24 to 30 months. As can be seen from the least squares constants in Table 10, males are 2.8, 7.8, 11.0, 15.6, 18.4, $8.6,6.6,7.6,28.2$, and 128.6 pounds heavier than females at birth and $3,6,9,12,18,24,30,36$, and 48 months of age respectively. The difference between the sexes increases up to 12 months of age and then decreases to 24 and 30 months. The least squares constants at 36 and 48 months show a marked difference between the average weights of males and females. It is thought that much of this difference is a result of more severe culling of males than females at these two ages. In general, the least squares means and effects of sex of calf agree with means reported in other studies $(10,11,13,24,25)$.

As shown in Table 9, the effects associated with month of birth are significant at all ages except 36 and 48 months. The effects of month of birth on weight at later ages is mainly a manifestation of the stage in the wet and dry weather cycle in which an animal reaches a given age. For example, those animals born in March, April, and May reach a year of age after having been weaned during the dry season and then surviving the dry season. The constants in Table 10 indicate that these animals are 14 to 20 pounds lighter than the mean at 12 months. Those animals born in July, August, September, and October are from 11 to 30 pounds heavier than the mean at one year. If the constants for 18 months are observed, it is seen that those animals born in July, August, September, and October are lighter than those born in March, April, and May. If a breeder wants to sell his cattle at 18 or 30 months of age, it appears that he should have his cows calve in December, January, February, or March. On the other hand, if he wants to sell at 24 or 36 months, he should have them calve in July, August, or September. The effects of month of birth on weights at later ages are mainly a reflection of the nutritional cycle through which the calves themselves have recently passed (11). The effects of month of birth on birth weight are 
likely manifestations of the nutritional cycle through which the dam passed while the calf was in utero.

The mean weights for those calves born in February and September and having weights every month up through three years are shown in Fig. 1. Those calves born in February grow well until the eighth month, which is October. At approximately 8 to 9 months the calves are weaned, and they start the dry season with no supplemental feeding. The mean weights from the 8 th through the 14 th month of life, or from October through the following April, are 211, 211, 214, 221, 215, 218, and 223 pounds respectively. These calves have gone six months with essentially no gain in weight. From April to the following October, the calves gain approximately 100 pounds; then during the second dry season through which they live they gain only 20 pounds. During the next wet season they gain another 100 pounds. Before those calves born in February reach 36 months of age they have gone through two periods of 6 months each of essentially no gain in weight. On observing the gains up to 36 months of calves born in September, it is seen that they go through two periods of 8 months each of essentially no growth. The constants for month of birth in Table 10 agree closely with the plotted curves of Fig. 1 even though they are based on different numbers.

Just why the effects associated with month of birth failed to be significant at 36 and 48 months is not known. It could be that by 3 and 4 years of age the animals have been through a sufficient number of nutritional cycles caused by the wet and dry seasons and exposed to other debilitating environmental factors to such an extent that month of birth becomes relatively unimportant as a source of weight variation. It might also be that culling on a weight basis has partially removed some of the variation associated with month of birth.

The mean squares associated with year of birth (see Table 9) are significant at all ages included in the study. Three likely causes of variation between year of birth are the differences in the severity and extent of the dry periods (thus more seriously limiting the pasture available in some years than in others), differences between years resulting from improved pastures and other management practices, and larger weights resulting from genetic improvement. In observing the least squares constants in Table 11, there appears to be no evidence for an increase in weight from the early to the late years. At the older ages the constants associated with year of birth are a conglomerate of the combination of genetic and environmental factors affecting the calf in utero and from birth to the specified age. Thus at 24 months of age calves born in 1949 were 108 pounds above average; this 108 pounds 


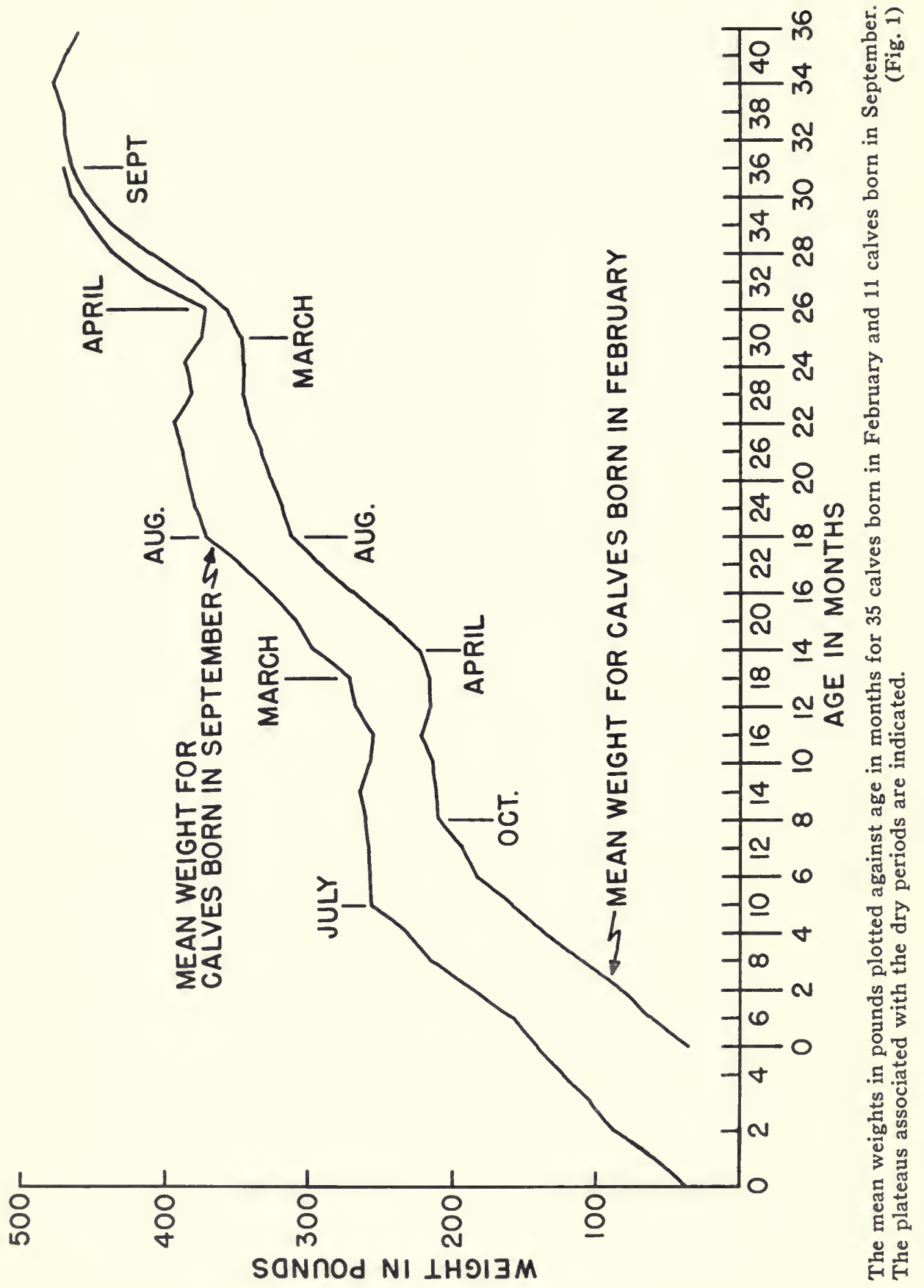


indicates that those calves born in 1949 enjoyed a favorable series of environmental occurrences from birth to 2 years, or were themselves a rather select group of calves, or were fortunate in both respects.

To determine if there were distinct linear trends in the weights of calves born from 1949 through 1964 the regressions of the least squares constants on year of birth (written as the numbers 1 through 16) were calculated for weights at birth and 12, 24, 36, and 48 months of age. The regression coefficients are shown in Table 12. The regression for birth weight on years indicates that birth weight has increased approximately 0.2 pound per year over the 16 years. All other regression coefficients are negative. Except for the extremely large positive constant associated with the year 1949, no other obvious trends exist to explain the negative regressions. If the constants in Table 11 for a given age are plotted against the years from 1949-1964, it is apparent that the constants for 1949 are unexpectedly large. This suggests that the cattle born in 1949 and included in these data were either a select group, or enjoyed a most fortunate sequence of environmental conditions, or possibly both. After eliminating the constants for 1949, no consistent trends associated with year of birth remained. There has been no consistent increase in weight at a given age in the last 15 years.

\section{Table 12. - The Regressions (b) of the Least Squares Constants on Year of Birth and Their Standard Errors $(\sigma)$}

\begin{tabular}{|c|c|c|c|c|c|}
\hline \multirow{2}{*}{ Statistic } & \multicolumn{5}{|c|}{ Age in months } \\
\hline & Birth & 12 & 24 & 36 & 48 \\
\hline 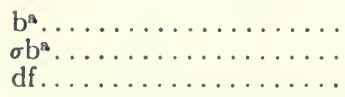 & $\begin{array}{l}+.22^{*} \\
14^{.08}\end{array}$ & $\begin{array}{l}-3.1^{*} \\
1.08 \\
14\end{array}$ & $\begin{array}{l}-4.4 \\
2.18 \\
13\end{array}$ & $\begin{array}{c}-18.7^{* *} \\
1.61 \\
12\end{array}$ & $\begin{array}{c}-1.6 \\
2.91 \\
11\end{array}$ \\
\hline
\end{tabular}

* Significant at the .02 level of probability.

* Significant at the .01 level of probability.

$\mathrm{a} b$ and $\sigma \mathrm{b}$ are in pounds.

The size of the least squares constants in Tables 10 and 11 indicates that before culling on a basis of fixed weight standards the weights of all calves should be adjusted for sex and for month and year of birth. For example, at 24 months of age those calves born in March are 34.6 pounds lighter than average while those born in August are 30.8 pounds heavier than average. The average weight at 24 months is 359.7 pounds; thus, those born in March are approximately 10 percent lighter than average while those born in August are approximately 9 percent heavier than average. To adjust for month of calving, the least squares con- 
stants in Table 10 can be used. For example, to adjust weight at 2 years, all those calves born in March should have 34.6 pounds added to their weight and those born in August should have 30.8 pounds subtracted from theirs. Such adjustments would yield weights similar to those resulting from having all calves born in the same month of the year. Adjustments for sex and year of birth can be accomplished in a similar way.

The mean squares for sires in Table 9 were obtained assuming that the sire effects were fixed. The effects associated with sires were significant up through 12 months of age. After 12 months, the sire effects were not significant in any case, and, in fact, at the last three ages the mean square for sires was less than the error mean square. This suggests that from 18 to 48 months factors are in operation which tend to equalize the means of the progeny groups. Examination of the mean weights for the progeny groups shown in Table 13 (which have been

\section{Table 13. - The Adjusted Mean Weights for the Progeny Groups ${ }^{\mathrm{a}}$}

\begin{tabular}{|c|c|c|c|c|c|c|c|c|c|c|}
\hline \multirow{2}{*}{ Sire } & \multicolumn{10}{|c|}{ Age in months } \\
\hline & Birth & 3 & 6 & 9 & 12 & 18 & 24 & 30 & 36 & 48 \\
\hline $\begin{array}{l}\text { nknown....... } \\
\ldots \ldots \ldots \ldots \ldots \ldots \\
9 \ldots \ldots \ldots \ldots \\
9 \ldots \ldots \ldots\end{array}$ & $\begin{array}{l}36 \\
40 \\
35 \\
37\end{array}$ & $\begin{array}{r}101 \\
89 \\
110 \\
94\end{array}$ & $\begin{array}{l}154 \\
127 \\
191 \\
146\end{array}$ & $\begin{array}{l}195 \\
166 \\
235 \\
189\end{array}$ & $\begin{array}{l}216 \\
194 \\
254 \\
229\end{array}$ & $\begin{array}{l}282 \\
243 \\
289 \\
279\end{array}$ & & & $\begin{array}{l}467 \\
459 \\
484 \\
503\end{array}$ & $\begin{array}{l}542 \\
567 \\
580\end{array}$ \\
\hline $\begin{array}{l}43 \ldots \ldots \ldots \ldots \\
25 \ldots \ldots \ldots \ldots \\
20 \ldots \ldots \ldots \ldots\end{array}$ & $\begin{array}{l}38 \\
35 \\
37 \\
33\end{array}$ & $\begin{array}{r}105 \\
113 \\
99 \\
114\end{array}$ & $\begin{array}{l}179 \\
165 \\
158 \\
182\end{array}$ & $\begin{array}{l}220 \\
209 \\
211 \\
222\end{array}$ & $\begin{array}{l}248 \\
238 \\
233 \\
255\end{array}$ & $\begin{array}{l}318 \\
294 \\
296 \\
295\end{array}$ & $\begin{array}{l}376 \\
365 \\
357 \\
383\end{array}$ & $\begin{array}{l}437 \\
427 \\
409 \\
427\end{array}$ & 478 & $\begin{array}{l}535 \\
546 \\
513 \\
529\end{array}$ \\
\hline $\begin{array}{l}37 \ldots \ldots \ldots \\
46 \ldots \ldots \ldots \\
122 \ldots \ldots \ldots \ldots \\
164 \ldots \ldots \ldots \ldots\end{array}$ & $\begin{array}{l}37 \\
36 \\
37 \\
38\end{array}$ & $\begin{array}{l}117 \\
105 \\
105 \\
118\end{array}$ & $\begin{array}{l}169 \\
159 \\
150 \\
174\end{array}$ & $\begin{array}{l}217 \\
196 \\
196 \\
207\end{array}$ & $\begin{array}{l}245 \\
235 \\
215 \\
233\end{array}$ & $\begin{array}{l}288 \\
295 \\
278 \\
294\end{array}$ & $\begin{array}{l}364 \\
367 \\
352 \\
359\end{array}$ & $\begin{array}{l}423 \\
441 \\
417 \\
413\end{array}$ & $\begin{array}{l}473 \\
459\end{array}$ & $\begin{array}{l}560 \\
559 \\
551 \\
510\end{array}$ \\
\hline $\begin{array}{l}1 \ldots \ldots \ldots \\
2 \ldots \ldots \ldots \\
1 \ldots \ldots \ldots \\
56 \ldots \ldots \ldots \\
\ldots \ldots \ldots\end{array}$ & $\begin{array}{l}36 \\
36 \\
36 \\
35\end{array}$ & $\begin{array}{l}115 \\
104 \\
113 \\
108\end{array}$ & $\begin{array}{l}170 \\
159 \\
169 \\
175\end{array}$ & $\begin{array}{l}208 \\
195 \\
208 \\
208\end{array}$ & $\begin{array}{l}236 \\
225 \\
235 \\
215\end{array}$ & $\begin{array}{l}29 \\
29 \\
29 \\
27\end{array}$ & $\begin{array}{l}364 \\
354 \\
367 \\
368\end{array}$ & $\begin{array}{l}422 \\
423 \\
427 \\
443\end{array}$ & $\begin{array}{l}464 \\
477\end{array}$ & $\begin{array}{l}562 \\
540 \\
549 \\
561\end{array}$ \\
\hline 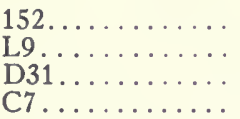 & $\begin{array}{l}40 \\
36 \\
35 \\
39\end{array}$ & $\begin{array}{l}102 \\
108 \\
109 \\
104\end{array}$ & $\begin{array}{l}143 \\
160 \\
163 \\
162\end{array}$ & $\begin{array}{l}211 \\
201 \\
206 \\
195\end{array}$ & $\begin{array}{l}236 \\
231 \\
231 \\
200\end{array}$ & $\begin{array}{l}272 \\
279 \\
295 \\
269\end{array}$ & $\begin{array}{l}365 \\
356 \\
357 \\
\ldots\end{array}$ & $\begin{array}{l}384 \\
433 \\
475 \\
\cdots\end{array}$ & $\begin{array}{l}480 \\
461 \\
\cdots \\
\cdots\end{array}$ & $\begin{array}{l}\ldots \\
\cdots \\
\cdots\end{array}$ \\
\hline $\begin{array}{l}\mathrm{R} 10 \ldots \ldots \ldots \\
\mathrm{D} 34 \ldots \ldots \ldots \ldots \\
\mathrm{R} 9 \ldots \ldots \ldots \ldots \\
\mathrm{K} 71 \ldots \ldots \ldots \ldots\end{array}$ & $\begin{array}{l}37 \\
35 \\
35 \\
33\end{array}$ & $\begin{array}{l}108 \\
101 \\
115 \\
102\end{array}$ & $\begin{array}{l}165 \\
147 \\
161 \\
153\end{array}$ & $\begin{array}{l}214 \\
190 \\
199 \\
207\end{array}$ & $\begin{array}{l}245 \\
221 \\
217 \\
242\end{array}$ & $\begin{array}{l}308 \\
\cdots \\
\cdots \\
\cdots\end{array}$ & $\begin{array}{l}\cdots \\
\cdots \\
\cdots \\
\cdots\end{array}$ & $\begin{array}{l}\cdots \\
\cdots \\
\cdots\end{array}$ & $\begin{array}{l}\cdots \\
\cdots \\
\cdots\end{array}$ & $\begin{array}{l}\cdots \\
\cdots \\
\cdots\end{array}$ \\
\hline & $\begin{array}{l}36 \\
38\end{array}$ & $\begin{array}{r}83 \\
111\end{array}$ & $\begin{array}{l}109 \\
168\end{array}$ & . & $\cdots$ & & $\begin{array}{l}\cdots \\
\cdots\end{array}$ & $\ldots$ & $\begin{array}{l}\cdots \\
\cdots\end{array}$ & \\
\hline L.S. $n$ & 36 & 106 & & 2 & 231 & 28 & 36 & 420 & 471 & 5 \\
\hline Raw means. . & 37 & 107 & & & 227 & & 349 & 418 & 461 & 502 \\
\hline
\end{tabular}

- All weights are in pounds.

b Least squares means. 
adjusted for sex of calf and year and month of birth) makes it apparent that some of the last sires used have some of the lowest means for a given age. These sires have not been in service long enough to have progeny older than 6 to 12 months; consequently, these sires are not included at the older ages. The fact that some sires do not have progeny at the older ages may be a cause of the relative decrease in the variation between progeny groups at the older ages. If culling according to some standard weight were practiced, this would tend to equalize the weights of the sire groups. There was reference to standards of culling in the Jones report (12), but whether culling according to set standards has been routinely practiced is not known. If early in their lives the progeny of a given sire were kept together but separate from the progeny of contemporary sires and then assigned to pastures at random in later life, this could help explain the significant variation between progeny groups from birth to one year followed by the nonsignificant differences at the older ages. It might also be that those animals still living at the older ages are those that were able to survive the ravages of a tropical environment, and variations in genotype for weight have little chance to be expressed after the demands and ravages of the rigorous environment have been met.

The constants for sex, year of birth, and month of birth shown in Tables 10 and 11 can be used to adjust the weights, thus leaving only the random variation between and within sires in the data. Such an adjustment was done, and the adjusted means for sires are shown in Table 13 while the between and within sire components of variance are shown in Table 14. Estimates of heritability of weight at the different ages can be obtained by using formula II.

$$
\text { II. } h^{2}=\frac{4 \sigma_{\mathrm{s}}^{2}}{\sigma_{\mathrm{w}}^{2}+\sigma_{\mathrm{s}}^{2}}
$$

In using formula II it is assumed that $\sigma_{s}^{2}$ is one-fourth of the additive genetic variance plus a small fraction of the additive by additive epistatic variance. Further, it is assumed that $\sigma_{\mathrm{w}}^{2}$ consists of threefourths of the additive genetic variance plus the dominance and environmental variance and the remainder of the epistatic variance. Thus, formula II is a fraction whose numerator is an estimate of the additive genetic variance and whose denominator is an estimate of the phenotypic variance.

In reality, $\sigma_{\mathrm{s}}^{2}$ contains one-fourth of the additive genetic variance, a small fraction of the additive by additive epistatic variance, plus any environmental factors which tend to make the progeny of a sire alike but different from the progeny of another sire. In general, 
Table 14. -- Estimates of the Between $\left(\sigma_{\mathrm{g}}^{2}\right)$ and Within $\left(\sigma_{\mathrm{W}}^{2}\right)$ Sire Components of Variance, Standard Deviations $\left(\sigma_{p}\right)$, and the Paternal Half Sib $\left(h_{1}^{2}\right)$ and Regression of Offspring on Dam $\left(h_{2}^{2}\right)$ Estimates of Heritability of Weight

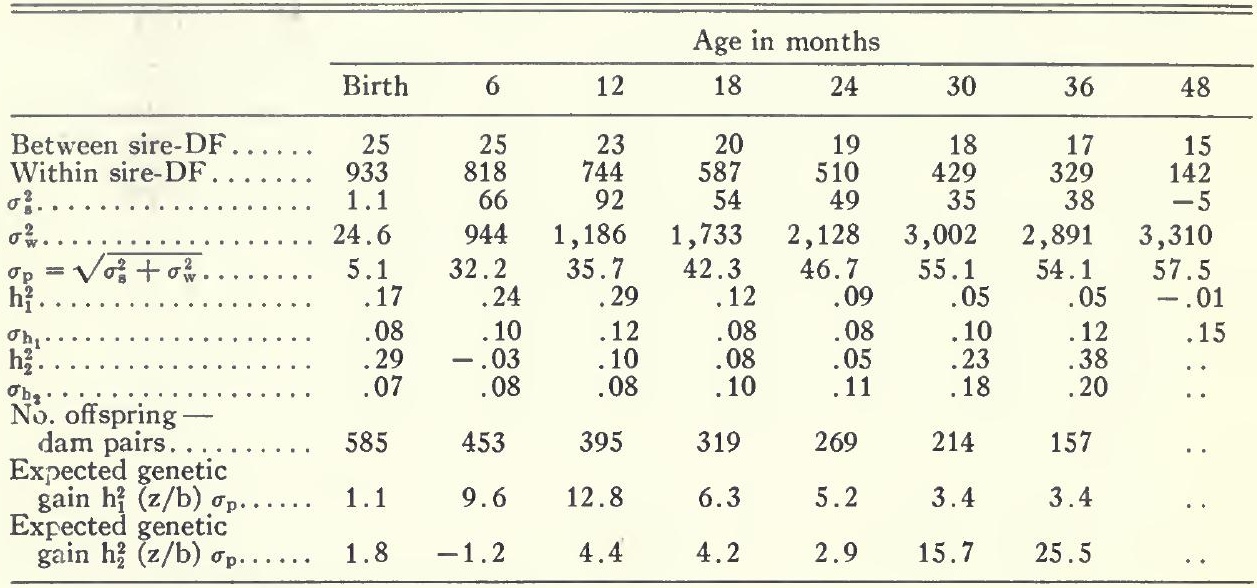

$(z / b)$ : assumed to be 1.24 .

$\sigma_{p}$ and expected genetic gains are in pounds.

such factors tend to make $\sigma_{\mathrm{s}}^{2}$ larger than it should be. Certain acts of man, such as culling, tend to equalize the progeny group means while at the same time leaving unaltered, or changing only slightly, the relative sizes of the variances within progeny groups. Thus, using formula II often results in biased estimates of heritability.

The estimates of heritability resulting from using formula II, commonly referred to as paternal half sib estimates of heritability, are shown in Table 14. To the extent that management practices allowed the environmental factors to affect progeny groups at random, the paternal half sib estimates are unbiased. It is likely that at the older ages the animals are a selected group and differences between progeny groups have been reduced. At the ages of 3 to 12 months it is possible that the sire components are larger than they should be because of management factors being confounded with sires.

Also shown in Table 14 are estimates of heritability obtained from the regression of offspring on dam. Before these estimates were derived, the weights were adjusted for year and month of birth and sex of animal by using the least squares constants of Tables 10 and 11 . The regressions were also derived on a basis of the variation between calves of the same sex born in the same month and year, but these regressions are not shown because they agreed so closely with those derived from the adjusted data. 
The paternal half sib estimates are relatively high at the younger ages, but gradually become smaller at the older ages. Conversely the regression estimates start out high, become small at the intermediate ages, and then become large again at the older ages. All paternal half sib estimates from birth to 12 months are significant, while none of the estimates after 12 months is significant. The only age at which the estimates are significantly different from each other is 6 months. The difference at 6 months is probably related to the fact that the calves have survived to this age mainly by suckling their dams. With the relatively large standard errors of the estimates of heritability, an elaborate interpretation of the significant difference would not be too meaningful.

The averages of the two estimates at birth, $6,12,18,24,30$, and 36 months of age are $0.23,0.11,0.20,0.10,0.07,0.14$, and 0.21 , respectively. In general, heritability of weight at a given age for the N'Dama is markedly lower than that found in most European breeds $(14,15,16)$. Weaning weight of beef cattle in the United States has a lower heritability than birth or yearling weight $(14,15)$. This is in agreement with the above averages at birth, 6 months, and 12 months.

From a study of the herd of White Fulani cattle at the Shika Stock Farm in northern Nigeria, Foster (8) reported heritabilities of birth weight of $0.19 \pm 0.15$ and $0.42 \pm 0.23$ respectively for the regression of offspring on dam and the paternal half sib estimates. For weight at 2 years the estimates were $0.08 \pm 0.12$ and $0.69 \pm 0.25$ respectively. The regression estimates are remarkably similar to those for the Musaia herd, while it is probable that the paternal half sib estimates reported by Foster are confounded with year to year environmental differences and, if they are, are thus too large.

The expected genetic gain per generation resulting from selecting for a single character can be expressed as follows:

$$
\text { III. } \Delta \mathrm{G}=\mathrm{h}^{2}(\mathrm{z} / \mathrm{b}) \sigma_{\mathrm{p}} \text {. }
$$

where $h^{2}$ is the heritability of the characteristic, b is the fraction of the population that must be saved to reproduce the next generation, $z$ is the height of the ordinate where a vertical line truncates the top b percentage of the population, and $\sigma_{\mathrm{p}}$ is the phenotypic standard deviation of the character. The term $\mathrm{z} / \mathrm{b}$ is the number of standard deviations that the mean of the selected group is expected to exceed the mean of the population. Values of $z, b$, and $z / b$ may be found in any table of the areas and ordinates of the normal curve. Fig. 2 should help explain the $(\mathrm{z} / \mathrm{b}) \sigma_{\mathrm{p}}$ part of formula III.

In Fig. 2, the mean of the selected group, $\overline{\mathrm{X}}_{\mathrm{b}}$, minus the mean of the entire population $\overline{\mathrm{X}}_{\mathrm{p}}$, is $\left(\overline{\mathrm{X}}_{\mathrm{s}}-\overline{\mathrm{X}}_{\mathrm{p}}\right)=(\mathrm{z} / \mathrm{b}) \sigma_{\mathrm{p}}$. The expected genetic 


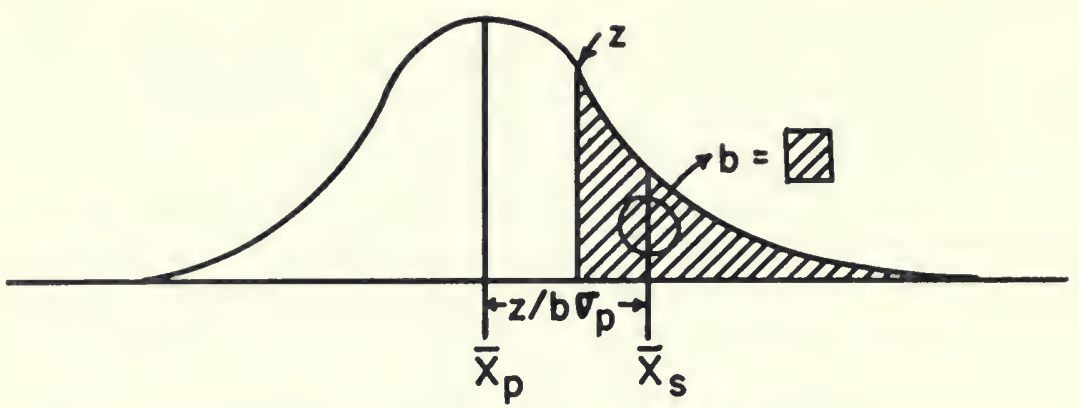

The amount by which the mean $\left(\bar{X}_{8}\right)$ of the top b percent of a normal population exceeds the mean $\left(\overline{\mathrm{X}}_{\mathrm{p}}\right)$ of the entire population.

$\mathrm{b}=$ percent of population saved.

$z=$ the point or ordinate where the line truncating the top $b$ percent cuts the normal curve.

$\begin{aligned} \sigma_{\mathrm{p}} & =\text { the standar } \\ \left(\overline{\mathrm{X}}_{\mathrm{q}}-\overline{\mathrm{X}}_{\mathrm{p}}\right) & =(\mathrm{z} / \mathrm{b}) \sigma_{\mathrm{p}} .\end{aligned}$

(Fig. 2)

or breeding value of the selected group is $\overline{\mathrm{X}}_{\mathrm{gs}}=\overline{\mathrm{X}}_{\mathrm{p}}+\mathrm{h}^{2}(\mathrm{z} / \mathrm{b}) \sigma_{\mathrm{p}}$ or it is $\mathrm{h}^{2}(\mathrm{z} / \mathrm{b}) \sigma_{\mathrm{p}}$ above the population mean, $\overline{\mathrm{X}}_{\mathrm{p}}$. If randomly drawn males and females from the fraction $b$ were mated, the resulting progeny would be expected to exceed the mean of the parental generation, $\overline{\mathrm{X}}_{\mathrm{p}}$, by the amount, $\mathrm{h}^{2}(\mathrm{z} / \mathrm{b}) \sigma_{\mathrm{p}}$.

Suppose now that we wanted to select the cattle at the Musaia station for weight at one year of age. What increase in weight at one year could be expected per generation of selection? Heritability at one year is estimated to be 0.29 , and $\sigma_{\mathrm{p}}$ is estimated to be 35.7 pounds. Keep in mind that the 35.7 pounds is the standard deviation remaining after having adjusted the weights at one year of age for month and year of birth and sex of the animal. Such adjustments usually increase the accuracy of selection. In a population of cattle such as that at the Musaia station it should be possible to perpetuate the herd by using only the top 5 percent of the males and the top 75 percent of the females for breeding purposes. By looking in a table of areas and ordinates of the normal curve, it can be found that the mean of the top 5 percent is 2.06 standard deviations above the mean of the population, while the mean of the top 75 percent is 0.42 standard deviation above the population mean. Except for sex linkage, males and females contribute equally to the next generation; thus the average $\mathrm{z} / \mathrm{b}$ is $(2.06 \pm 0.42) / 2=1.24$. Putting these three values together, the expected genetic gain per generation is found to be:

$$
\Delta \mathrm{G}=\mathrm{h}^{2}(\mathrm{z} / \mathrm{b}) \sigma_{\mathrm{p}}=0.29(1.24)(35.7)=12.8 \text { pounds }
$$


Shown in Table 14 are the expected genetic gains per generation for various ages; an average $\mathrm{z} / \mathrm{b}$ of 1.24 was assumed.

The next question of importance is the generation interval. The average age at calving was 39.4 months and the average calving interval was 15.5 months. To replace herself, the average cow would have to calve approximately three times. Thus the average generation interval would be approximately 86 months or 7 years. The gain per year would thus be approximately 1.8 pounds for weight at one year of age.

Koch and Clark $(14,15)$ found heritability of yearling weight of beef cattle in Nebraska to be 0.47 and 0.43 respectively and standard deviations of 56.4 pounds and 56.7 pounds. Assuming a z/b of 1.24 the expected genetic gains per generation are 32.9 and 30.2 pounds respectively. Further, the generation interval is approximately 5 years; thus, the expected genetic gains per year are 6.6 and 6.0 respectively. To say the least, the expected genetic gain per year for the N'Dama under Musaia conditions is comparatively small.

It seems that the average age at first calving could be reduced to 24 months instead of 39.4 months, thus shortening the generation interval by 15.4 months. Further, it would seem that at least 2.5 months could be taken off the average calving interval. By doing these two things the average generation interval could be shortened by approximately 23 months.

Having cows calve at a younger age and shortening the calving interval seem like inconsequential changes, but are they? From Table 12 it can be seen that the average weight of N'Dama females at 2 years is 356.4 pounds while weights for Guernsey and Holstein females (Table $15)$ are 860 and 1,143 pounds respectively. Are the small size and old age at first calving mainly a genetic characteristic of the N'Dama breed or are they mainly a result of the general nutritional level under which

Table 15. - The Mean Weights in Pounds of N'Dama Females at the Musaia Station and Holstein and Guernsey Females in the University of Illinois Dairy Herd ${ }^{a}$

\begin{tabular}{|c|c|c|c|c|c|c|c|c|c|}
\hline & \multicolumn{9}{|c|}{ Age in months } \\
\hline & Birth & 3 & 6 & 12 & 18 & 24 & 30 & 36 & 48 \\
\hline N'Dama $\%$ 's $(\mathrm{N})$ & 35 & 102 & 154 & 222 & 283 & 356 & 422 & 457 & 482 \\
\hline U. of I. Holstein 9 's $(\mathrm{H})$. & 89 & 216 & 379 & 683 & 939 & 1,143 & 1,185 & 1,278 & 1,313 \\
\hline U. of I. Guernsey $९$ 's (G) & 65 & 150 & 301 & 551 & 707 & 860 & 900 & 967 & 1,050 \\
\hline $\mathrm{H} / \mathrm{N} \ldots \ldots \ldots \ldots \ldots$ & 2.54 & $4 \quad 2.12$ & 2.46 & 53.08 & $8 \quad 3.32$ & 3.21 & 2.81 & 2.80 & 2.72 \\
\hline 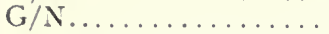 & 1.86 & $5 \quad 1.47$ & 1.95 & 2.48 & 32.50 & 2.42 & 2.13 & 2.12 & 2.18 \\
\hline
\end{tabular}

"The number of Holsteins ranged from 150-170, while the number of Guernseys ranged from 89-110 at the different ages. The numbers for the N'Dama are shown in Tables 6 and 7. 
the N'Dama is kept? Even if the generation interval is shortened substantially, the gain per generation is still small.

\section{Comparisons of weights of N'Dama, Holstein, and Guernsey cows}

Shown in Table 15 are the mean weights of females of three breeds at different ages. The weights for the N'Dama are the least squares weights of females derived from the means and sex constants of Table 10. These means are comparable to those reported in other studies (11, $20,21,24,25)$. The means for Holsteins and Guernseys are the least squares means of 160 Holsteins and 98 Guernseys in the crossbreeding project at the University of Illinois, some of which are included in (29). The mean weights for Holsteins and Guernseys at 24, 30, 36, and 48 months of age have been adjusted for stage of lactation and gestation. The last two lines of Table 15 indicate that the weights of the N'Dama compare most favorably with those of the Guernsey and Holstein at 3 months and least favorably at 12,18 , and 24 months. At 3 months the N'Dama is suckling its dam and thriving, while by 12,18 , and 24 months it has endured the effects of weaning and the ravages of one or two dry periods. The Guernseys and Holsteins in the University of Illinois herd are allowed to suckle their dams for one day, after which they are put on feed which includes a given amount of milk up to the time the calves are approximately 3 months of age.

At one year of age both the Guernsey and Holstein are heavier than the N'Dama is at 4 years. The weights of Hereford, Angus, and Shorthorns under similar feeding regimes would be close to that of the Holstein. The question arises: to what extent is the difference between the Musaia N'Dama weights and the University of Illinois Holstein and Guernsey weights genetic? To improve the production of beef, it is presently of great economic value to Sierra Leone to find out how the N'Dama compares under Musaia conditions to breeds such as the Hereford, Santa Gertrudis, Brown Swiss, and Boran, or to crosses of the N'Dama with these breeds. Further, it is potentially of greater economic importance to determine how the N'Dama compares with other breeds or crosses to other breeds under more optimum nutritional, management, and health conditions. According to a report (1) on the herd at the Firestone plantation in Liberia, crosses of Brown Swiss to the native cattle thrive in West Africa when fed and managed well. A report (2) on crosses of Holsteins and Zebu in Nigeria shows similar results. It may be economically unsound to spend years trying to genetically improve the N'Dama to levels now existing in other breeds. With frozen semen and artificial insemination, germ plasm from a large variety of 
breeds and strains could be used to produce crossbred cattle that might be readily adapted to the conditions existing in Sierra Leone.

There may be some calving difficulty resulting from mating the small N'Dama cow to bulls of larger breeds, but the frequency of such difficulty is not necessarily high. Some of the Zebu cattle have been mated to Holsteins (2) and Brown Swiss with an apparent low incidence of calving difficulty. Further, breeds of dogs differing far more in relative size than the known cattle breeds have been crossed with only a low incidence of difficulty at parturition. It is likely that the frequency of calving difficulty will differ from one breed of bull to another or from bull to bull of the same breed, and there is no accurate way to predict which sire or breed of sire may cause a high frequency of difficult calving without making crosses. Resistance to trypanosomes appears to exist in the crossbreds (28).

\section{Slaughter data}

Shown in Table 16 are the mean weights for various body parts of 54 N'Dama cattle. The 54 animals consisted of 51 males and 3 females. The ages at slaughter ranged from 32 to 49 months, with an average age of 39.1 months. The live weights ranged from 381 to 624 pounds, with a mean of 512.1 pounds. Both of the extreme animals were 40 months of age. In the third line of Table 16 are the percentages of live weight accounted for by the various parts. The sum of the percentages is 100 ,

\section{Table 16. - The Average Weights in Pounds of Body Parts of 54 N'Dama and 124 University of Illinois Holstein, Holstein X Angus, Charolaise $X$ Angus, and Angus Cattle}

\begin{tabular}{|c|c|c|c|c|c|c|c|c|c|c|}
\hline & $\mathrm{N}$ & $\mathrm{U}$ & $\begin{array}{l}\text { Car- } \\
\text { cass }\end{array}$ & Head & Neck & $\begin{array}{l}\text { Heart, } \\
\text { liver, } \\
\text { and } \\
\text { kidneys }\end{array}$ & $\begin{array}{l}\text { Feet } \\
\text { and } \\
\text { tail }\end{array}$ & Offal & Skin & $\begin{array}{c}\text { Live } \\
\text { weight }\end{array}$ \\
\hline \multirow{5}{*}{$\begin{array}{l}\text { Mean weights of parts } \\
\text { (N'Dama)......... } \\
\text { Standard deviations } \\
\text { (N'Dama).......... } \\
\text { Percent of live weight } \\
\text { (N'Dama)......... } \\
\text { Mean weights of parts } \\
\text { (U. of I. cattle)..... } \\
\text { Percent of live weights } \\
\text { (U. of I. cattle)..... }\end{array}$} & 54 & $171.4^{\mathrm{a}}$ & 213.1 & 31.1 & 13.2 & 10.4 & 13.8 & 29.0 & 30.1 & 512.1 \\
\hline & . & 34.5 & 28.0 & 3.3 & 2.6 & 2.1 & 1.7 & 6.1 & 3.6 & 51.2 \\
\hline & . & 33.5 & 41.6 & 6.1 & 2.6 & 2.0 & 2.7 & 5.7 & 5.8 & $\ldots$ \\
\hline & 124 & $153.4^{b}$ & 548.2 & 26.4 & & $14.5^{\circ}$ & 15.0 & $98.1^{d}$ & 67.4 & 923.0 \\
\hline & . & 16.6 & 59.4 & 2.9 & $\ldots$ & 1.6 & 1.6 & 10.6 & 7.3 & $\ldots$ \\
\hline
\end{tabular}

a $U$ for the N'Dama $\overline{\bar{F}}$ Live weight - sum of all other parts, so $U=512.1-340.7 \overline{\bar{b}}=171.4$.
b $U=153.4$ pounds included 80.5 pounds for content of $G$. I. tract, 32.8 pounds blood and 40.1 pounds unaccounted for.

c 14.5 pounds is the weight of the heart and liver only. The kidneys are included with the carcass.

d 98.1 pounds includes 40.2 pounds empty G. I. tract, 36.4 pounds mesenteric fat and 21.5 pounds for thymus, spleen, heart fat, lungs, etc. 
since the sum of the means for the various parts is equal to the mean live weight. It is interesting to note that the carcass accounts for only 41.6 percent of the live weight. Dairy steers in the United States have a dressing percentage around 55 to 57 percent, while beef steers dress 60 to 63 percent. The carcass data for the N'Dama were obtained from animals put in a warri at approximately 6:00 p.m. and slaughtered the following morning at approximately 8:00. The animals were therefore without feed and water for approximately 14 hours. The dressing percentage for animals slaughtered under local conditions would be subject to many factors as the animals may have been walked for great distances, dehydrated, and hungry before slaughter. O Korie et al. (24) reported a dressing percentage of 52.6 to 54.1 percent for N'Dama grown on improved pastures.

Also shown in Table 16 are data on 124 steers from an experiment conducted at the University of Illinois (3) on the influence of type on beef carcass components. The steers consisted of equal numbers of Holstein, Holstein $\times$ Angus, Charolaise $\times$ Angus, and Angus cattle. Approximately one-fourth of each breed group was slaughtered at each of the weights $675,850,1,025$ and 1,200 pounds. The average weight when taken off feed was 923 pounds, and the average age at slaughter was approximately 12 months. In comparing the N'Dama data with the Illinois data, the difference in the fraction of live weight accounted for by the carcass is amazing. The carcass as defined at the University of Illinois includes part of the neck and the kidneys. If for the N'Dama data one adds the weight of the neck and one-third of the weight of the heart, liver, and kidneys to the carcass weight, this accounts for 44.9 percent of the live weight. For the Illinois data the carcass accounts for 59.4 percent of the live weight. There is a vast difference between slaughtering a 923 pound animal at 12 months of age and obtaining a carcass accounting for approximately 60 percent of the live weight, and slaughtering one of 512 pounds at 39 months of age and obtaining a carcass accounting for 45 percent of the live weight.

It would be of interest to know to what extent these differences are genetic and to what extent they reflect other factors. Letroteur (17) has reported carcass data for one N'Dama and one Peul female. It is known that, in general, the smaller the animal the larger the proportion of total weight that is made up of viscera, internal organs, weight of skin, and so forth. Further, the dressing percentage is affected to a small extent by the prior feeding history of the cattle; grass fed animals tend to have a much greater "fill" and less abdominal fat than cattle fed a more concentrated ration. In spite of the vast differences in feeding and management, it is probable that a good part of the difference in 
dressing percentage is of genetic origin. The results of $\mathrm{O}$ Korie et al. (24) suggest this.

In connection with dressing percentage it should be pointed out that in Sierra Leone a much greater proportion of a beef animal, sheep, or pig is sold and eaten than in Western Europe or the United States. In general the head, skin, entire G.I. tract, lungs, feet, and spleen are sold at one-half the price per pound for that demanded for the remainder of the carcass (26). This will probably continue to be the practice for many years among both the less affluent and more affluent segments of the native population. Thus a low dressing percentage is not the serious economic loss in Sierra Leone that it is in Western Europe and the United States.

Shown in Table 17 are the simple correlations between the various parts of live weight. In this case the parts of live weight are the weights of the carcass, head, neck, heart, liver and kidneys, feet and tail, offal, skin, and the unaccounted for fraction, $U$. Those correlations between live weight and parts are generally higher than those between the various parts because of the part-whole relationship between a part and live weight. In general the highest correlations between the various parts are those involving the carcass while the lowest are those involving $U$,

Table 17. - The Standard Partial Regressions of the Body Parts on the Live Weight of the Animal, the Correlations Between the Parts, and the Parts and Live Weight ${ }^{\mathrm{a}}$

\begin{tabular}{|c|c|c|c|c|c|c|c|c|c|c|}
\hline \multirow{2}{*}{\multicolumn{2}{|c|}{$\begin{array}{l}\text { Standard partial } \\
\text { regressions } \\
\text { of live weight } \\
\text { on the parts }\end{array}$}} & $\mathrm{U}^{\mathrm{b}}$ & $\begin{array}{l}\text { Car- } \\
\text { cass }\end{array}$ & Head & Neck & $\begin{array}{c}\text { Heart, } \\
\text { liver, } \\
\text { and } \\
\text { kidneys }\end{array}$ & $\begin{array}{l}\text { Feet } \\
\text { and } \\
\text { tail }\end{array}$ & Offal & Skin & $\begin{array}{c}\text { Live } \\
\text { weight }\end{array}$ \\
\hline & & .676 & .546 & .064 & .051 & .051 & .033 & .118 & .070 & \\
\hline \multirow[t]{2}{*}{$\begin{array}{l}\text { Simple } \\
\text { correlations }\end{array}$} & \multirow{2}{*}{\multicolumn{2}{|c|}{$\begin{array}{l}\text { Ub } \\
\text { Carcass } \\
\text { Head } \\
\text { Neck } \\
\text { Heart, liver, } \\
\text { and kidneys } \\
\text { Feet and tail } \\
\text { Offal } \\
\text { Skin }\end{array}$}} & -.044 & $\begin{array}{l}.049 \\
.235\end{array}$ & $\begin{array}{r}-.040 \\
.357 \\
.427\end{array}$ & $\begin{array}{l}.222 \\
.600 \\
.300 \\
.369\end{array}$ & $\begin{array}{l}.120 \\
.581 \\
.176 \\
.127\end{array}$ & $\begin{array}{l}.018 \\
.419 \\
.336 \\
.388\end{array}$ & $\begin{array}{l}.427 \\
.427 \\
.760 \\
.308\end{array}$ & $\begin{array}{l}.678 \\
.673 \\
.358 \\
.333\end{array}$ \\
\hline & & & & & & & .330 & $\begin{array}{l}.562 \\
.247\end{array}$ & $\begin{array}{l}.354 \\
.382 \\
.224\end{array}$ & $\begin{array}{l}.659 \\
.519 \\
.447 \\
.516\end{array}$ \\
\hline
\end{tabular}

a These correlations and regressions are based on the data resulting from slaughtering 54 N'Dama animals ( 51 males and 3 females).

b U = Weight unaccounted for = live weight - sum of all other parts. Correlations larger than .273 and .354 are significant at the .05 and .01 levels of probability, respectively. The average age at slaughter was $39.1 \pm 39$ months. The standard deviation of age at slaughter was 2.8 months. 
the unaccounted for weight. This would be expected as the carcass is the largest of the parts actually weighed, and $U$ includes errors which force the sum of the other parts and $U$ to equal the live weight. The highest correlation between parts is that of 0.76 between the weight of the head and the weight of the skin. No obvious cause of this high correlation is readily apparent. The second highest is that between the combined weight of the heart, liver, and kidneys and the weight of the carcass.

\section{Selection for heavier animals at a given age}

Just what size cow would be most profitable in Sierra Leone is not known; however, it seems that effort should be exerted to obtain cattle that produce more meat at a given age. For the N'Dama to produce more meat at a given age, it is necessary to select for heavier weights at a given age, say 12 or 18 months, and for heavier carcass weight.

To effectively carry out such a program all female replacements could be chosen on a basis of their adjusted weight at the chosen age. If selection were on a basis of adjusted weight at one year of age, which of the following two females should be culled? Female A was born in August of 1959 and weighed 240 pounds at one year. Female B was born in March of 1960 and weighed 220 pounds at one year. By examining the constants for month and year of birth in Tables 10 and 11 the reader can find the adjusted weights to be:

$$
\begin{aligned}
& \text { adjusted weight for } \mathrm{A}=240-(18.0)-(1.3)=220.7 \\
& \text { adjusted weight for } \mathrm{B}=220+(20.4)+(36.9)=277.3
\end{aligned}
$$

On the basis of weight at one year, Cow B appears to be the superior of the two cows. As a practical procedure, the adjusted yearling weight of all cows available for reproduction could be computed once a year by using appropriate constants for year and month of birth. The cows could then be ranked from lightest to heaviest on a basis of adjusted weight. After considering all other debilitating attributes, one should be able to cull 15 to 20 percent of the remaining females of breeding age on a basis of adjusted yearling weight and still maintain a constant herd size. If it is desired to increase herd size, less than 15 to 20 percent could be culled; if herd size is to be reduced, a higher fraction could be culled. As can readily be seen, there is little opportunity to genetically change cattle by restricting selection to females only.

Most of the genetic progress from breeding cattle must come from a wise choice and judicious use of sires. When natural service is used, one can successfully maintain a constant herd size by using only the top 5 percent of the males, and their paternal half sibs could be adjusted 
for year and month of birth and sex. Selection then could be on a basis of the male's own weight and the average of the sire family of which he is a part. A suitable index is:

$$
\begin{aligned}
\hat{G}_{m} & =\bar{P}+h^{2}\left[\frac{1-r}{1-t}\right](P-\bar{P}) \\
& +h^{2}\left[\frac{r-t}{1-t}\right]\left[\frac{N}{1+(N-1) t}\right](Y-\bar{P})
\end{aligned}
$$

where:

$\hat{\mathrm{G}}_{\mathrm{m}}=$ expected breeding value for yearling weight of the male being considered.

$\overline{\mathrm{P}}=$ the mean yearling weight for the herd.

$\mathrm{h}^{2}=$ heritability of adjusted yearling weight.

$\mathrm{r}=$ the relationship between paternal half sibs, usually .25 .

$\mathrm{t}=$ phenotypic correlation between paternal half sibs and is $\sigma_{\mathrm{s}}^{2} /\left(\sigma_{\mathrm{s}}^{2}+\sigma_{\mathrm{w}}^{2}\right)$; (see Table 14$)$.

$\mathrm{P}=$ adjusted yearling weight of the male calf concerned.

$\mathrm{N}=$ number of paternal half sibs, including the male calf concerned, in the family to which the male calf belongs.

$\mathrm{Y}=$ the average of the adjusted yearling weights of the paternal half sibs of the male calf concerned. The male calf's own adjusted weight $(\mathrm{P})$ is included in the average.

The practical procedure for using such an index would be to compute the adjusted yearling weights for all animals, males and females. The constants for year of birth, month of birth, and sex of calf in Tables 10 and 11 could be used for adjusting the data. The next step would be to compute $\mathrm{Y}$, the average of each sire family, and record $\mathrm{Y}$ and $\mathrm{N}$ along with the $\mathrm{P}$ for each male. It would seem wise to choose the top 10 percent of the male calves on a basis of the index and then at a later date get rid of half of these on a basis of the slaughter data on their paternal half sibs; it seems desirable to increase the fraction of live weight accounted for by the carcass (see Table 16).

The adjustment for year of birth could be avoided by using a new battery of sires each year. Progress from selection is faster if herd sires are turned over rapidly, and the Musaia herd is large enough to use new sires each year. In this way all sires used in a given year would be born in the same year. Such a system would also be compatible with the index suggested for choosing sires. The Musaia station could easily use 8 to 10 new sires per year, as little is gained by making $\mathrm{N}$ in the above index larger than 25. 


\section{Discussion}

Tables 14, 15, and 16 show an amazingly small size, low dressing percentage, and low expected genetic gain per generation for the N'Dama breed. These tables raise a number of questions about cattle production in Sierra Leone. If cattle production is to continue under conditions where the cattle must depend solely on grazing on unimproved pastures of tropical grasses, with no supplemental feeding of stored feed during the dry period, and under a nomadic system of management, then perhaps the N'Dama is as well suited as any breed for such a system of cattle production; however, this has not been proved. On the other hand, if cattle are to provide a major part of the food for the people of Sierra Leone, experiments to seek answers to the following questions should be begun in the immediate future.

1. What is the ecological distribution of trypanosomiasis in Sierra Leone? How can trypanosomiasis be controlled?

2. How do other breeds of cattle and crosses of the N'Dama with other breeds compare with the N'Dama at Musaia as producers of meat and milk?

3. What crops can be grown, harvested, and stored to provide palatable dry or succulent roughage of high nutritive content?

4. What crops can be grown to supply low-cost concentrate feed? How will the cost of this home-grown concentrate compare with the cost of imported oil cakes?

5. Can a sound and dependable cattle slaughtering and marketing system be developed?

6. What steps can be taken to speed up the further development of the cattle settlement scheme?

The first question is concerned with the disease, trypanosomiasis. One of the main assets claimed for the N'Dama breed is its reported tolerance to trypanosomiasis (28). The nature of this tolerance is not well documented. The tolerance appears to be present in crossbreds of N'Dama to European breeds (28). A comprehensive and thorough study of the incidence and the ecological distribution of the disease in Sierra Leone is of paramount importance. Further there is a great need for work on the prevention and treatment of trypanosomiasis. A recent and comprehensive review by Williamson $(30,31)$ indicates that chemotherapy of trypanosomiasis may not be as futile as it once was.

In the fall of 1965, when feed was scarce, many N'Dama at Musaia appeared to be showing symptoms of disease infections. Treatment of the afflicted cattle with drugs customarily used to control the known and possible infections were of no avail. The veterinarian at Teko 
diagnosed the presence of trypanosomiasis in some affected animals. Treatment specific for this infection cleared up the problem. Meanwhile three N'Dama that were sold during this period by the station to cattle owners outside the station died of trypanosomiasis. Thus the N'Dama cattle do become infected (they are tolerant but not resistant), but it is only under extremely adverse conditions that the N'Dama cattle exhibit symptoms of this infection. Further, this indicates that chemotherapy can be successful.

The N'Dama cattle at the Musaia station are vaccinated routinely for anthrax, blackquarter, hemorrhagic-septicemia, and rinderpest. They are treated routinely for worms and ticks. Also they are weighed once a month and kept in fairly open pasture. It has been reported (18) that trypanosomiasis can be partially controlled by keeping the cattle in large open pastures from which all bush has been removed, and by vaccination at regular intervals during the rainy season, or both. If other beef breeds were crossed with the N'Dama, it would seem that little additional cost and labor would be involved to vaccinate for trypanosomiasis once a month during the rainy season if necessary. When one considers the size of the N'Dama as compared to the Brown Swiss, Hereford, Holstein, Shorthorn, Sanata Gertrudis, or Boran the medical costs per pound of beef produced would probably be less for crosses of these breeds with the N'Dama even though they might have to be treated periodically for trypanosomiasis.

Question two concerns the qualifications of the N'Dama breed as a producer of meat and milk. By examining Tables 3, 14, 15, and 16 it can be seen that the performance of the N'Dama is poor as a producer of milk and meat. On the other hand it is not known to what extent the differences between the N'Dama and other breeds as shown in Tables 3, 14, 15, and 16 are genetic. Further, Table 14 indicates that in its present genetic and environmental state, genetically increasing the weight of the N'Dama at a given age by selection is an extremely slow and tedious process. Montsma $(20,21)$ has shown that when the N'Dama is given supplemental feeding it produces barely enough milk to raise a calf. That the N'Dama is a poor milker is further substantiated by Gaudefroy (9) and Jones (12). If crosses of the N'Dama to breeds such as the Brown Swiss, Hereford, Santa Gertrudis, or Boran can be protected from disease and given supplemental feeding in their younger ages, an experiment should be begun to determine how well crosses of these breeds with N'Dama would perform at Musaia. At present there are no data to support an argument that the N'Dama breed is the only breed that should be grown at Musaia. In fact the work of Anliker (1) and Armour et al. (2) suggests that crosses with 
other breeds show much promise. There are no data on the relative performances of the N'Dama, other breeds, and crosses of N'Dama and other breeds under Musaia conditions. If crosses of N'Dama and other breeds are superior to or only equal to the N'Dama under Musaia conditions, it is unwise to limit the gene pool and selection program to the N'Dama.

It is not good economic or husbandry management to take 3 years to grow an animal to acceptable market weight when it can be done in one-half to two-thirds of the time with supplemental feeding in the dry period. There is an economic loss in extra labor, feed for maintenance, medical costs, and death losses concomitant with the longer period required for reaching the market weight. Husbandry-wise, it is biologically more efficient to keep animals growing at a steady rate from birth to market weight. If Sierra Leone is to have an economically healthy cattle industry, it must grow crops to produce feed to supplement the pastures.

Suppose that a cattle owner establishes good husbandry practices and is able to produce good quality beef economically; what will he do with it? There must be a sound and dependable cattle marketing and slaughtering system established or all of the improved husbandry practices will have been for naught. If a sound slaughtering and marketing system is developed, it will serve as an impetus to the establishment of good husbandry practices. It may even lead to the establishment of cattle feeders who buy young cattle and feed them for slaughter.

It is almost mandatory that Sierra Leone cattle farmers be permanently settled in order to have them preserve and store feed for use in the dry season, establish and maintain improved pastures, and fully utilize good husbandry practices. The Fula cattle owners are probably much like other cattlemen the world over; once they see that a husbandry practice yields economic results they will try to adopt such a practice. If the cattle settlement scheme becomes widely accepted, the Musaia station could be more effective in its function of demonstrating good husbandry and management practices to the cattle owners. Activities such as the present field days held at the station could become a more vital part of the station's activities and thus be more helpful in distributing knowledge of animal husbandry practices to cattle owners.

It is believed that there are no short-cut, crash programs that will establish an efficient and productive cattle industry in Sierra Leone. Such an industry must develop simultaneously with and be compatible with and supplementary to other agricultural and nonagricultural industries. To achieve an efficient and economic cattle industry the cattle 
producers of Sierra Leone must have access to and make use of modern technology. This will require much vocational teaching and education, both in the schools and for adults. Extensive vocational and technical education programs should be established with the idea of not expecting measurable results until after approximately 20 or 25 years. It will take much time to develop vocational and technical skills in the population to the extent that an efficient and economical cattle industry can exist. With its relatively large areas of range, its adequate rainfall, its numbers of cattle, and its need for meat, a cattle industry should be a substantial part of the agricultural industry of Sierra Leone.

\section{References}

1. AnLIKER, W. L. 1964. The cattle breeding program of the Firestone Plantations Company. Report No. 75 of the Firestone Plantations Company Research Division Botanical Department. Monrovia, Liberia.

2. Armour, J., LeE, R. P., ANd Ross, J. G. 1961. Observations on a cross breeding experiment with cattle in Nigeria. Trop. Agr. (Trin.) 38:319-323.

3. Breidenstein, B. C. 1965. An experiment conducted at the University of Illinois on the influence of type on beef carcass components. (Unpublished data.)

4. Cash, J. G., Fryman, L. R., Harpestad, G. W., and Johnson, R. V. 1965. Summary of Illinois Dairy Herd Improvement Association for 1964-65 testing year. University of Illinois, Cooperative Extension Service, Department of Dairy Science, Urbana.

5. Dickinson, F. N., and Touchrerry, R. W. 1961. Livability of purebred vs. crossbred dairy cattle. J. Dairy Sci. $44: 879-887$.

6. Doutressoule, G. 1947. L'elevage en Afrique-Occidentale Francaise. Paris: Editions Larose.

7. Faulkner, D. E., And Brown, J. D. 1953. The improvement of cattle in British colonial territories in Africa. Publication No. 3 of the Colonial Advisory Council of Agriculture Animal Health and Forestry. Reprinted 1954. Her Majesty's Stationery Office.

8. Foster, W. H. 1960. The breeding of white Fulani cattle at Shika, Nigera. SAMARU Research Bulletin No. 2. Regional Research Station, Ministry of Agriculture, SAMARU, Zaria, Northern Nigeria.

9. Gaudefroy-Demombynes, P. 1961. Lactation of N'Dama cows at CRA Bambey. Agron. Trop. (Paris) 16:417-432.

10. Hill, D. H. 1964. Animal breeding and improvement in Nigeria. Outlook Agr. $4: 80-85$.

11. Hill, D. H., ANd Upton, M. 1964. Growth performance of ranch reared N'Dama and Keketu cattle and their crosses in the derived Guinea savanna zone, Western Nigeria. Trop. Agr. (Trin.) $41: 121-128$.

12. Jones, T. S. 1953. Report on the Musaia station submitted to the Ministry of Agriculture of Sierra Leone.

13. Joshi, N. R., Mclaughlin, E. A., and Phillips, R. W. 1957. Types and breeds of African cattle. FAO Agricultural Studies Publication No. 37. Food and Agriculture Organization of the United Nations. Rome, Italy.

14. Koch, R. M., AND ClaRK, R. T. 1955. Genetic and environmental relationships among economic characters in beef cattle. I. Correlations among paternal and maternal half-sibs. J. Animal Sci. $14: 775-785$. 
15. Кoch, R. M., and ClaRK, R. T. 1955. Genetic and environmental relationships among economic characters in beef cattle. II. Correlations between offspring and dam and offspring and sire. J. Animal Sci. 14:786-791.

16. Legault, C. R., and Touchberry, R. W. 1962. Heritability of birth weight and its relationship with production in dairy cattle. J. Dairy Sci. $45: 1226-$ 1233.

17. Letroteur, R. 1957. Rendements compare's en muscles consommobles, os, graisse, apone'vroses. Rev. Elev. Mid. Ve't. Pays Trop. 10:41-44.

18. Levine, N. D. 1961. Protozoan parasites of domestic animals and of man. 412 pp. Burges Publishing Co., Minneapolis, Minnesota.

19. MAson, I. L. 1951. The classification of West African livestock. Technical Communication No. 7, Commonwealth Bureau of Animal Breeding and Genetics. Commonwealth Agricultural Bureau, Farnham Royal, England.

20. Montsma, G. 1960. Observations of milk yield and calf growth and conversion rate on three types of cattle in Ghana. Trop. Agr. (Trin.) 37:293-302.

21. Montsma, G. 1962. Observations of milk yield and calf growth and conversion rate on three types of cattle in Ghana. II. Effects of plane of nutrition. Trop. Agr. (Trin.) 39:123-129.

22. Murray, A. K. 1958. The Fula cattle owners of Northern Sierra Leone, their cattle and methods of Management. Trop. Agr. (Trin.) 35:102-112.

23. National Academy of Sciences. National Research Council. 1965. Report by the study group on animal diseases in Africa. Washington, D.C.

24. O Korie, I. I., Hill, D. H., AND MCIlroy, R. J. 1965. The productivity and nutritive value of tropical grass/legume pastures rotationally grazed by N'Dama cattle at Ibadan, Nigeria. J. Agr. Sci. 64 :235.

25. Pagot, J., ANd DeLaine, R. 1959. E'tude biometrique de la croissance des taurins. Reu. E'lev. P'med. Ve't. Pays Trop. $12: 405-416$.

26. Roche, J. 1965. Oral communication.

27. Sierra Leone Department of Agriculture. 1959. Report for the year 1957. Freetown, Govt. Printers.

28. Stewart, J. L. 1951. The West African shorthorn cattle, their value to Africa as trypanosomiasis resistant animals. Vet. Rec. $63: 454-457$.

29. Touchberry, R. W., ANd Bereskin, B. 1966. Crossbreeding dairy cattle II. Comparisons of weights and body measurements of purebred Holstein and Guernsey females and their reciprocal crossbreds. J. Dairy Sci. 49:647-658.

30. Williamson, J. 1962. Chemotherapy and chemoprophylaxis of African trypanosomiasis. Exp. Parasitol. 12:274-322.

31. Williamson, J. 1962. Chemotherapy and chemoprophylaxis of African trypanosomiasis. Exp. Parasitol. $12: 323-367$. 


\section{ACKNOWLEDGMENTS}

One doesn't become an authority on raising cattle in the tropics in a short period of time, and I was in Africa for only five weeks. During this period I was most fortunate to talk at length with men who had spent long periods of time in the tropics and to study a large volume of records and notes collected over a period of approximately 18 years at the Musaia Animal Husbandry Station. It is hoped that this report is a reasonably accurate report of what was said and recorded.

The animal husbandry station at Musaia was established with funds provided by the Colonial Development and Welfare Office in London. Its studies were done under the auspices of the Sierra Leone Department of Agriculture until 1961 and subsequently under the Ministry of Agriculture and Natural Resources. The records kept on the animals at the station proved to be adequate for the present work and they reflect the punctuality with which each officer, despite frequent changes of office, collected and recorded all the data used here. I wish to thank all those officers without whose industry and foresight this work would not have been possible. The following officers were in charge of the station for the periods indicated: Mr. Capstick, Agricultural Officer, 1946-1948; Mr. J. M. Dent, Agricultural Officer, 19481951; Mr. J. W. Wells, Agricultural Superintendent, 1950-1954; Mr. A. K. Murray, Agricultural Officer, 1954-1956; Mr. B. R. Shaw, Agricultural Officer, 1956-1957; Mr. J. M. Dent, Senior Agricultural Officer, 1957-1958; Mr. C. R. Dunton, Agricultural Officer, 1958; Mr. H. E. G. Morgan, Senior Agricultural Officer, 19581962; and Mr. J. Roche, Agricultural Officer, 1961 to present. There are numerous other officers who have contributed much, but it is not possible to mention them all here.

I am especially grateful to Mr. John Roche, the present agricultural officer, whose comments and advice were most interesting and constructive and of paramount importance in writing this report. Thanks are due to Dr. Joseph Kastelic, Research Coordinator, and Dr. W. N. Thompson, Chief of Party, University of Illinois/USAID at Niala University College, Sierra Leone, for getting me to the records and the records to me and for help in many ways. Finally I express appreciation for the cooperation of the Ministry of Agriculture and Natural Resources of the government of Sierra Leone, Niala University, the University of Illinois, and the University of Illinois/USAID program in Sierra Leone which made the study possible.

R. W. Touchberry 


\section{RECOMMENDATIONS}

1. The operation of the beef herd at the Musaia Animal Husbandry Station should be continued.

2. In the routine operation of the beef herd there are a number of practices that should be continued; among these are:

a. Weighing animals routinely.

b. Giving excellent medical care and keeping complete medical histories on the individual animals.

c. Keeping accurate records of weights, calving dates, parentage, cause of death or disposal, and date of death or disposal.

d. Establishing improved pastures and searching for better pasture plants.

3. Using a fraction of the herd, approximately 200 females of breeding age, selection for weight at a given age (12 or 18 months) should be practiced within this closed herd of N'Dama cattle.

a. All weights should be adjusted for month and year of calving before deciding which animals to cull and which to keep.

b. Females should be culled or kept on a basis of their own adiusted weight.

c. Males to be used as herd sires should be chosen on a basis of their own adjusted weight and the mean adjusted weight of their paternal half sibs (formula on page 35).

4. The other portion of the herd, approximately 200 females of breeding age, should be used in a crossbreeding program; frozen semen from a number of bulls of each of 3 or 4 breeds should be used. This experiment should be carefully designed and developed in conjunction with Recommendations 3, 5, and 6.

5. Establish the ecological distribution of trypanosomiasis in Sierra Leone and explore various avenues of combating or controlling the disease.

6. Use a segment of the facilities at the station to determine what crops can be grown, harvested, and stored to provide economical, palatable, and nutritious roughage and concentrates for the dry season. 


UNIVERSITY OF ILLINOIS-URBANA

Q.630.71L6B

BULLETIN. URBANA

C008

7241967

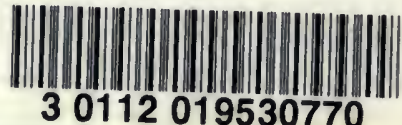

